\title{
SYSTEMATICS OF COMPOSITIONS IN HISTORICAL GARDENS AS A DESIGN SUPPORT IN CONTEMPORARY DESIGN CONCEPTS
}

\section{SYSTEMATYKA ZAŁOŻEŃ HISTORYCZNYCH OGRODÓW JAKO ELEMENT WSPOMAGAJĄCY WSPÓŁCZESNE KONCEPCJE PROJEKTOWE}

\author{
Teresa Bardzinska-Bonenberg \\ D.Sc., Ph.D. in Architecture \\ Orcid: 0000-0002-1998-7306 \\ Professor of Bydgoszcz University of Science and Technology, Poland \\ Bydgoszcz, Poland
}

\section{Agata Bonenberg}

prof. dr hab. inż. arch.

Orcid: 0000-0003-1618-4417

Poznan University of Technology, Poland

Faculty of Architecture

\begin{abstract}
People always valued nature around them so the gardens accompanied their houses and residences from the ancient times. Some features of garden compositions were recurring in historical periods differing only in some aspects. In contemporary gardens they are repeated again. To assess the coincidences, a short graphic analysis of the basic features of historical gardens was developed. A tool that has allowed to identify differences and similarities between old and contemporary is the tabulation of composition schemes of well-known historic gardens and comparing the results with the features of the recent developments. This allowed us to investigate whether the same elements of composition, despite 21 st century changes, apply today.
\end{abstract}

Key words: residential garden, historical establishments, garden layout, composition, contemporary gardens, repeated solutions.

\section{STRESZCZENIE}

Ludzie zawsze cenili otaczającą przyrodę, więc od najdawniejszych czasów ogrody towarzyszyły ich domom i rezydencjom. Niektóre formy ogrodowych kompozycji powtarzały się we wielu okresach historycznych różniąc się w niewielki sposób. We współczesnych ogrodach elementy te są powtarzane ponownie. Aby ocenić te zbieżności została przeprowadzona krótka graficzna analiza 
podstawowych cech ogrodów historycznych. Narzędziem, które pozwoliło na określenie różnic i podobieństw pomiędzy dawnymi i dzisiejszymi rozwiązaniami jest zapis typów schematów kompozycyjnych znanych historycznych ogrodów i zestawienie ich z cechami najnowszych realizacji. Pozwoliło to na zbadanie czy te same elementy kompozycji, pomimo zmian XXI wieku są stosowane dziś.

Słowa kluczowe: ogród rezydencjonalny, założenie historyczne, plan ogrodu, kompozycja, współczesne ogrody, powtarzane rozwiązania.

\section{INTRODUCTION}

The aim of the study was to determine whether and to what extent the principles of garden composition that we know from historical establishments are applied today in contemporary solutions. What is the extent of the changes and what do they stem from. This is a continuation of research conducted for the past five years by a Polish-Chinese team: Bardzinska-Bonenberg T., Bonenberg A., Bonenberg W., Liu Shoufang.

The scope of research in the part dealing with the development of the Table 1. (Garden composition schemes) includes literature on European gardens from the earliest times, including those created under the influence of other cultures. The section on contemporary gardens (20th and 21st century) includes a discussion of European concepts created by well-known architects and landscape architects. This part of the work made it possible to determine in what direction contemporary garden art, related to places of residence, is developing.

The research methods used in this study are: analysis of literature and graphical materials, including inventory of past and contemporary garden establishments, synthetic record of solutions, and organizing the results in a tabular form. An important element of the research was the observation of garden establishments in situ (this applies to Europe). It is a methodology similar to that used in the natural sciences, where the spectrum of research extends between material world, animate and inanimate at different stages the process. Hence the necessity of using specific research tools, adjusted to the given research problem.

\section{EVOLUTION OF COMPOSITION RULES THROUGHOUT THE HISTORY}

A description of the development of garden forms with references to their connections with the volumes of palaces and later houses can be found in the published chapters: Residences and Their Gardens and Garden - The Pursuit of Harmony in the Modern Times (Bardzinska-Bonenberg T., Bonenberg A., Bonenberg W., 2021 and Bardzinska-Bonenberg T., Bonenberg A., Liu S., 2021). The analysis of the occurring spatial relations and garden plans showed that the elements of their compositions are repeated in different epochs, appearing at different scales and taking different places in the hierarchy of the whole composition. It is with this in mind that the following analysis of this phenomenon has been carried out. This part of the study contains diagrams of compositional arrangements of gardens from ancient times to the present. Twentieth and twenty-first century solutions are discussed further, providing a basis for a summary of the research findings.

Table 1.: Overview of historical garden composition schemes

\begin{tabular}{llll} 
Group & Type & Name of garden composition & Scheme \\
\hline A & A1 & simple single-axis arrangement \\
& A2 & $\begin{array}{l}\text { single-axle asymmetric arrangement with an added lateral ele- } \\
\text { ment }\end{array}$
\end{tabular}


A3. single-axis arrangement with inclusions of axial composition

A4 single-axis arrangement with inclusions of orthogonal composition

A5 single-axis arrangement with inclusions of free composition

A6 single-axis arrangement with inclusions of central composition

A7 single-axis arrangement with inclusions of radial composition
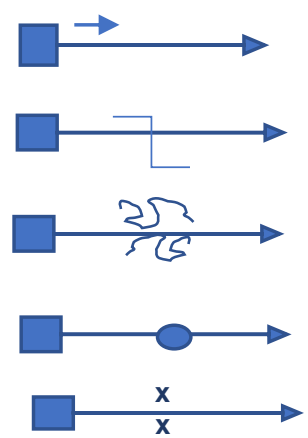

B B1 arrangement symmetric to two axes

B2 arrangement symmetric to two axes, with inclusions of axial composition

B3 arrangement symmetric to two axes with inclusions of orthogonal composition

B4 arrangement symmetric to two axes with inclusions of free composition

B5 arrangement symmetrical to two axes with inclusions of central composition

B6 arrangement symmetrical to two axes with inclusions of radial composition

arrangement symmetrical to two axes with inclusions of radial
composition

\begin{tabular}{lll}
\hline C & C1 & central establishment \\
& C2 & central establishment with inclusions of axial composition
\end{tabular}

C2 central establishment with inclusions of axial composition

C3 central establishment with orthogonal inclusions

C4 central establishment with inclusions of free composition

C5 central establishment with inclusions of free composition

C6 central establishment with inclusions of radial composition

\begin{tabular}{ccc} 
& C6 & central establishment with inclusions of radial composition \\
\hline D & D1 & triaxial/tridigitate arrangement \\
D2 & triaxial/tridigitate arrangement with inclusions composed axially \\
D3 & $\begin{array}{l}\text { triaxial/tridigitate arrangement with inclusions composed orthog- } \\
\text { onally } \\
\text { D4 }\end{array}$ & $\begin{array}{l}\text { triaxial/tridigitate arrangement with inclusions composed freely } \\
\text { triaxial/tridigitate arrangement with inclusions composed central- } \\
\text { D5 }\end{array}$ \\
D6 & $\begin{array}{l}\text { triaxial/tridigitate arrangement with inclusions composed radially } \\
\text { the }\end{array}$
\end{tabular}

D6 triaxial/tridigitate arrangement with inclusions composed radially
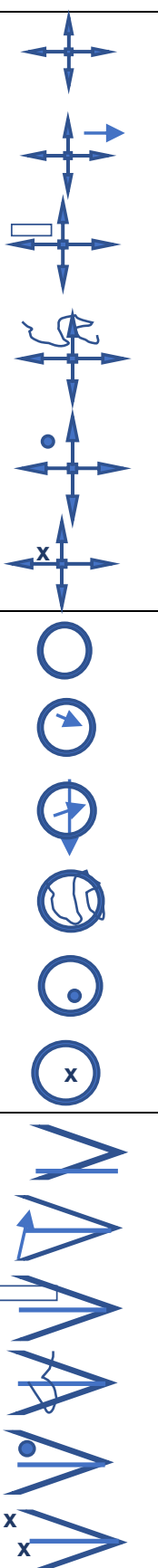


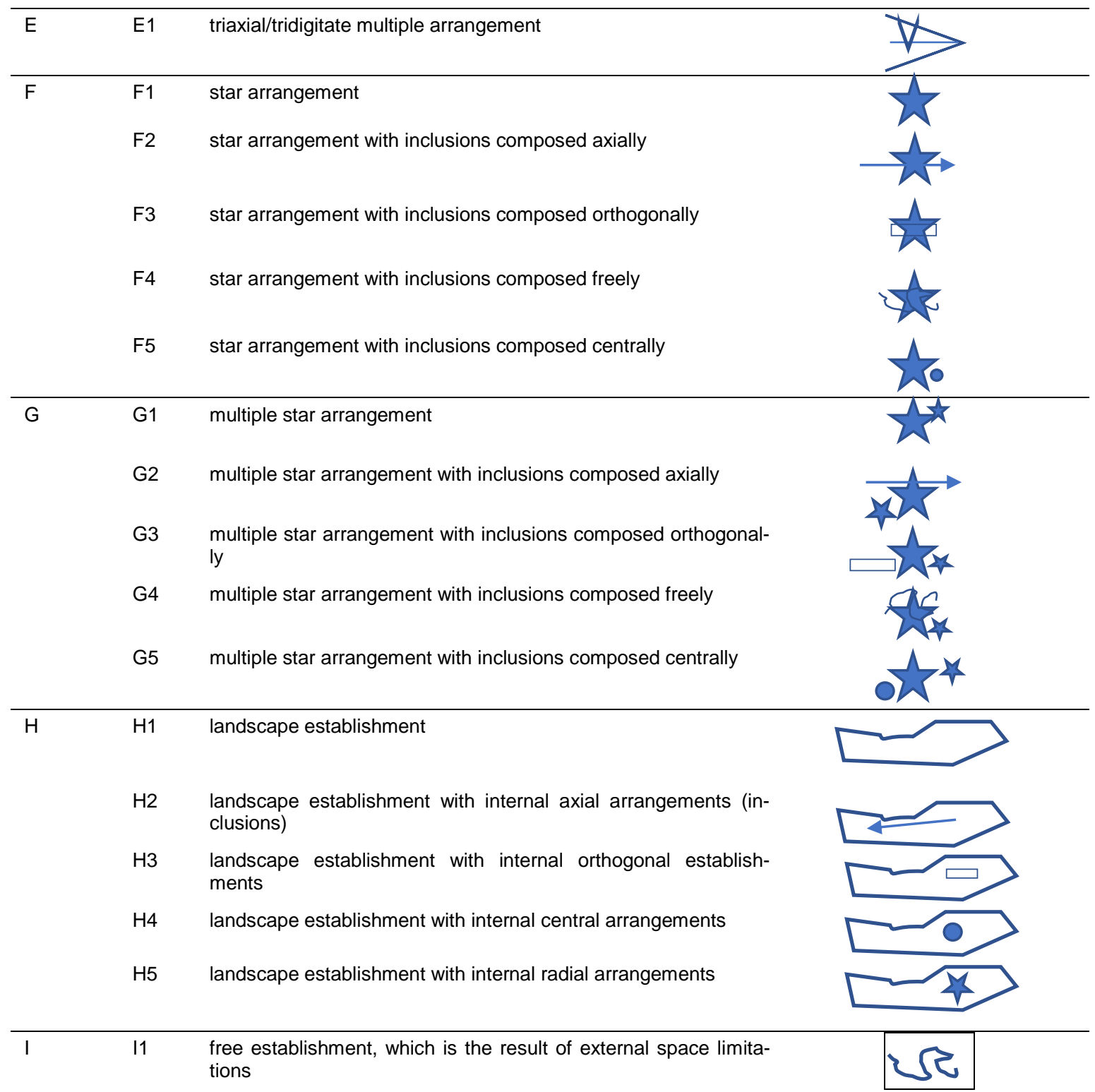

\section{ANCIENT TIMES}

The gardens of Ancient Egypt were composed axially just like the representative architecture they accompanied. Not only the whole establishment was subordinated to one axis, but also the fragments standing out in this whole. This is evident in the polychrome depicting the residence of Senefer, a dignitary at the court of Amenhotep II of the $18^{\text {th }}$ Dynasty, found in his tomb at Thebes. (Rice M., 1999, pp. 12-13) Pools with accompanying arbours, trees and rushes formed axial compositions of a lower order. The whole represents TYPE A3 garden. During the reign of the same dynasty, in a period of religious schism and changes in almost all walks of life, the new capital Telel-Amarna was built with the Pharaoh's palace. The palace-garden establishment was composed along one axis and was accompanied by a similar garden arrangement with trees and buildings. This is TYPE A2 garden. In the Fayum Depression, flooded by the waters of the Nile, Lake Moeris 
was formed, where a hunting ground for the rulers of the Middle Kingdom existed on an island. (Manning J.G., 2003, pp. 101-102) It was kept as a natural ground, with woods, meadows and wetlands. It was the oldest known garden of TYPE H1.

The temple garden, composed axially and forming a terraced, central approach from the Nile was the foreground of the temple of Hatshepsut. It is known that the axial arrangement of the establishment with a processional road was emphasized by trees placed on both sides on successive rock terraces. Bowls carved in the rock and filled with Nile silt testify to the existence of a terraced garden establishment. It was probably TYPE A1 (Fig. 1.)

The gardens in the atria of ancient Greek houses were axially shaped. Not much is known about them. From the entrance to the tablinum, the main visual axis ran across the impluvium.

The Roman house was similarly shaped. It usually had several courtyards, peristyle, with pools, surrounded by colonnades. Axial composition was a method of emphasizing the representative character of buildings and their associated gardens. This is clearly visible in villa complexes belonging to Roman aristocrats like Pliny's Villa representing TYPE C2. Only in exceptional cases were establishments of considerable scale freely formed, as at the villa of Emperor Hadrian at Tivoli near Rome and the villa of Emperor Tiberius at Anacapri. There, however, the individual elements of the ensemble had an axial, central and orthogonal composition. TYPE H1-H5

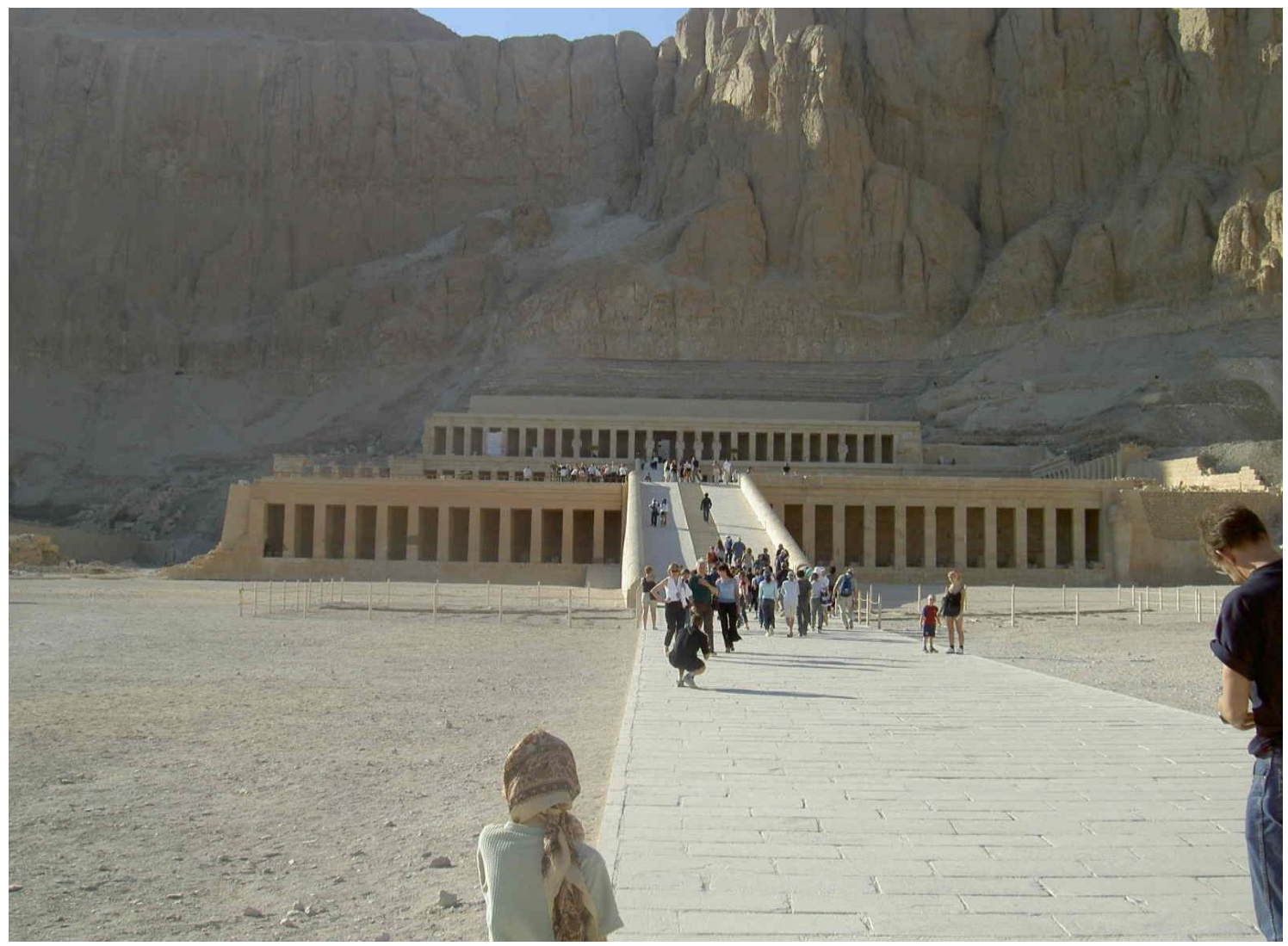

Fig. 1. Temple of Queen Hatshepsut (Egypt). The terraces were planted with vegetation set in pots forged in rock. Source: photo by A. Januchta-Szostak

Ryc. 1. Świątynia Królowej Hatszepsut (Egipt). Tarasy były obsadzone roślinami umieszczonymi w wykutych w skale donicach. Żródło: fot. A. Januchta-Szostak 


\section{MEDIEVAL TIMES}

The monastery gardens complemented the buildings, filling in the rectangular or square garth. It was crossed by paths creating a geometrical arrangement with a central point emphasized by a sculpture or a well. (Fig. 2) They represent TYPE B1 and C1 of the garden scheme. Plant material was associated with religious symbolism, and the proportions of churches, monastery buildings and gardens had their justification in the Holy Scriptures saying that the Lord God created the world according to measure, number and weight. (Catechism of the Catholic Church, p. 299) The remaining spaces, according to the preserved plans and graphic representations of the monasteries, consisted of regularly spaced, rectangular or square beds (TYPE C4). (Majdecki L., p.68).

The castle gardens made use of small free spaces in the fortress or between the walls, and thus depended on the shape and lighting of the nooks intended for them. Because of its location on the castle, the gardens were used by the ruler and the court. Known as hortus conclusus, they were often irregular green interiors furnished with small flower beds and climbers on trellises and walls. Earthen benches covered with grass made modest furnishing. This is a TYPE I1 garden, with a free arrangement forced by the limitations of the plot on which it was situated.

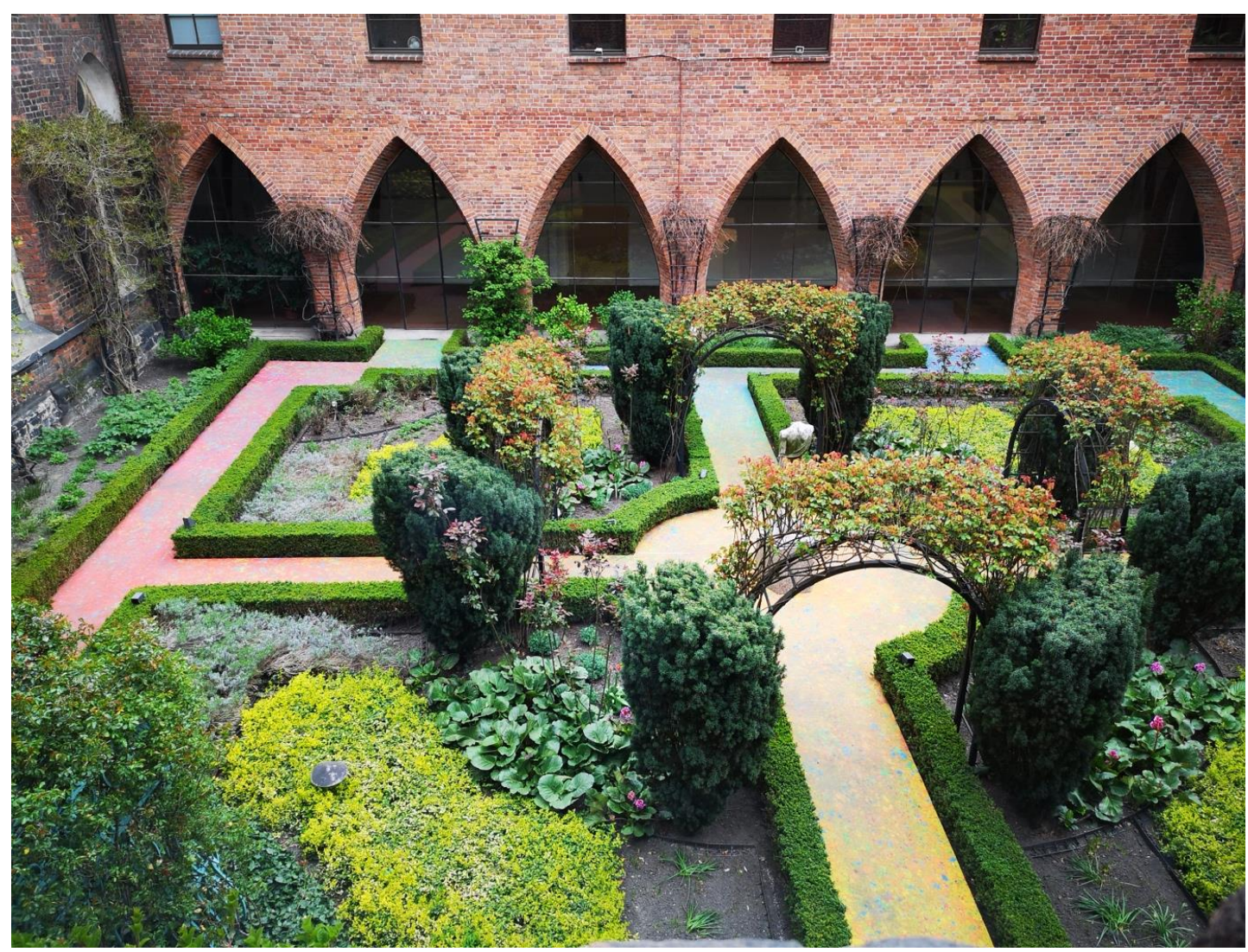

Fig. 2. Viridary in Architecture Museum (former Dominician convent) in Wroclaw (Poland). Source: photo author Ryc. 2. Wirydarz Muzeum Architektury (dawny klasztor dominikański) we Wrocławiu (Polska). Źródło: zdjęcie autor

\section{EARLY MODERN ERA - RENAISSANCE AND BAROQUE}

Renaissance residences of the villa type integrated architecture, greenery, small architecture, and the scale of these establishments grew over time reaching areas of 4-5 ha. 
Italian gardeners, like architects, took the square as their module. Quarters of this shape may have been planted with short vegetation creating flower parterres or bosquets if filled with trees. Parterres were divided into smaller, geometric areas by a low hedge and filled with herbs and flowers. Terraces were formed on the slopes, and in the most favourable places, scenic openings were introduced for distant views. However, as a rule the renaissance garden was clearly separated from the surrounding landscape (TYPES A1 and A4). In large-scale establishments ramps and stairs appeared, as well as mazes of hedges and viewing mounds, introducing internal, independent orthogonal and central forms (TYPE A4 and A6), as well as vertical elements. Smaller gardens were surrounded by an outer wall or hedge, creating an enclosed interior. (Fig. 3) At some distance from the main establishment there may have been a giardino semplici - a utility and economic garden of the residence. It had geometric divisions but an indeterminate shape (TYPE C4).

Renaissance garden establishments owed their clarity to the use of clear axes and geometric forms used in the superior and subordinated parts of the composition. (TYPE A3)

The beginning of the Baroque attitude in garden art was marked from 1660 onwards, by the construction of the Versailles establishment, although the Vaux-le Vicomte had previously developed the form of a Baroque residence. In England at the same time Hampton Court was extended with a baroque large-scale establishment, near Vienna in 1696 Schönbrunn Palace was completed and in Russia between 1714-25 the Tsarist Peterhof Palace was built. Following the example of the rulers, the aristocracy also built magnificent residences. The gardens, like the palaces were scaled up, consisting of almost independent parts, and the water devices used there made use of the latest discoveries of physics and achievements of technology (Hobhouse P., 2007, p. 156)

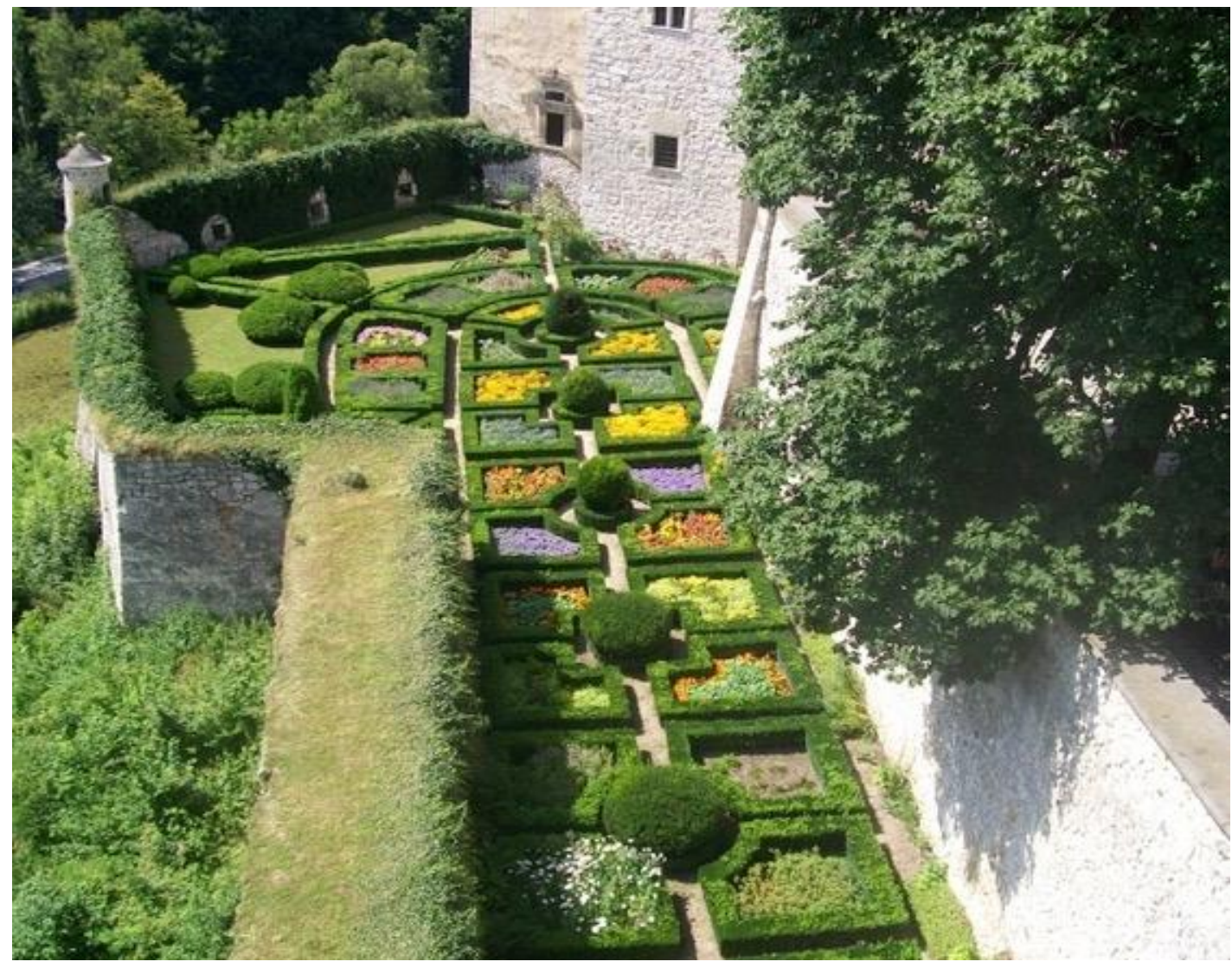

Fig. 3. Reconstructed Renaissance gardens at Pieskowa Skała Castle (Poland). Source: phot. author Rys. 3. Zrekonstruowane renesansowe ogrody na zamku Pieskowa Skała (Polska). Źródło: fot. autor 


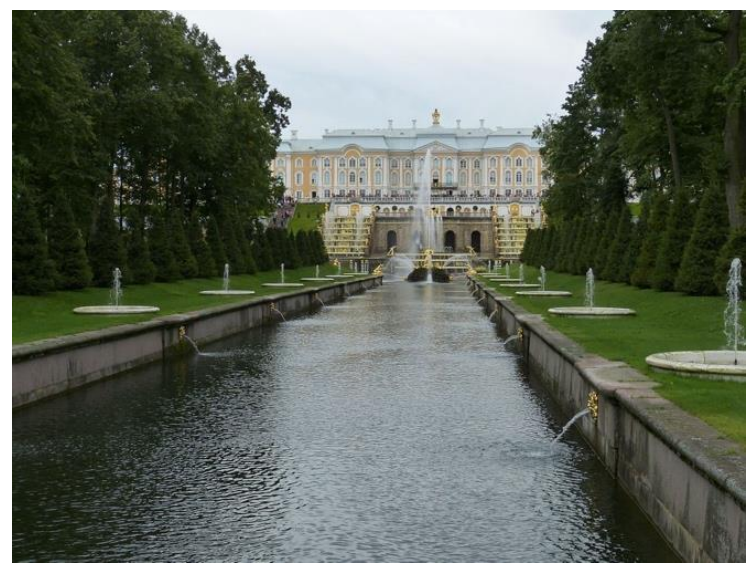

Fig. 4. Peterhof Palace (Russia). Main water axis of a Baroque composition of the garden. Source: phot. G. Potaev Ryc. 4. Pałac Peterhof (Rosja). Główna oś wodna barokowej kompozycji ogrodu. Źródło: phot. G. Potaev

The horizontal planes of parterres and vertical walls of greenery, sculptures, and the use of alleys and pools of water, cascades and fountains were richer than in the Renaissance. The quarters had the shape of an elongated rectangles with planned "cut-outs". Bosques became an integral part of Baroque establishments, and their interiors hid arbours and objects serving entertainment purposes. (Hobhouse P., 2007, p. 156) The common axis of the composition included the palace and the garden. Diagonal alleys diverged from it, forming threeaxial/tridigitate arrangements that led towards the wooded parts of the garden. The main axis organized the dynamic composition of triaxial and star-shaped alleys: TYPE F1. The compositions of the subsequent quarters make use of almost all geometric variants: TYPE F2, TYPE F3, TYPE F5.

Triaxial solutions TYPE D1; were used not only at Versailles this form was widely used in Europe. Compositions of TYPE D2, D3, D5, D6 dominated in the palace-garden establishment of Vaux-leVicomte.

The last of the great Baroque residences was the Peterhof Palace near St. Petersburg, the summer refuge of Tsar Peter II. (Fig. 4) The garden planned along the coast of the Gulf of Finland runs into it with a promenade and a water channel - elements of the main axis of the whole establishment. To this axis the body of the palace, main garden and the entrance garden were subordinated (TYPE A1-A4, A6-A7). By the palace, located on the slope, on a transverse axis (TYPE A4) a water cascade of one hundred and forty fountains was created. On its two sides the alleys form almost symmetrical, star-shaped, arrangements (TYPE A7). The motif of domination over land, but also over the sea, is as clear here as in other establishments built for European monarchs of the time.

Over-scaling the gardens in the Baroque era changed their structure and the way they were perceived. Immense spaces were assigned to diverse functions, and each was arranged differently. The use of elongated parterres and, above all, of alleys crossing or diverging at an acute angle greatly disturbed the possibility of a holistic reception of the arrangement of the gardens by its users (TYPE G1).

\section{REGULAR AND INFORMAL LAYOUTS OF 18TH CENTURY GARDENS}

Antoine-Joseph Dezallier d'Argenville introduced the concept of naturalness in the garden in the second edition of his work La théorie et la pratique du jardinage in 1713. By this he meant the use of lawns on shaped planes, ramps and steps, climbing plants and trellises (Lauterbach I., 2018) This coincided with new trends in art: the abandonment of atelier work by painters and the going out into the open air by early artists gave rise to a turn to landscape painting. In France these were Claude Lorrain (1600-1682), Nicolas Poussin (1594-1665), in England, Sir Joshua Reynolds (17231792), Thomas Gainsborough (1727-1788) and later, John Constable (1776-1837). 
In 1709 , painter and later garden architect and designer, William Kent (1685-1748) after a stay in Italy, with the statement: "All gardening is landscape painting" defined a new direction in the design of English gardens. (Hunt J. D., Dixon J., 2003.) The Grand Tour, which was undertaken by members of the upper classes and artists, influenced a change in tastes: the beauty of European, especially Italian landscapes caused an understanding of landscape painting, as well as new expectations towards gardens. Trade contacts with Far Eastern and South Asian countries resulted in an influx of objects representing a different aesthetic. People's actions played out against the landscape and vegetation that provided the backdrop.

The technical side of the implementation of landscape gardens of the 18th century requiring large earthworks was made possible by the engineering knowledge developed for the needs of the army.

The famous Chiswick Garden design by William Kent and Lord Burlington (built from 1729) created after their "Italian" voyage exemplifies the blending of two concepts: axial and landscape garden design. (Fig. 5, 6.) However, an axial arrangement prevails: the main alley is enclosed by symmetrical Chiswick House, and the garden area is composed on a tridigitate alley arrangement. (TYPE D1). Between them and to the north and south of them smaller sections of the garden are composed in different ways: centrally, orthogonally, star-shaped, freely (TYPES D4, D5, D6) rendering this part of the garden quite informal. Inspirations from the Italian landscape are a leading motif in the whole establishment mainly due to the selection of plants.
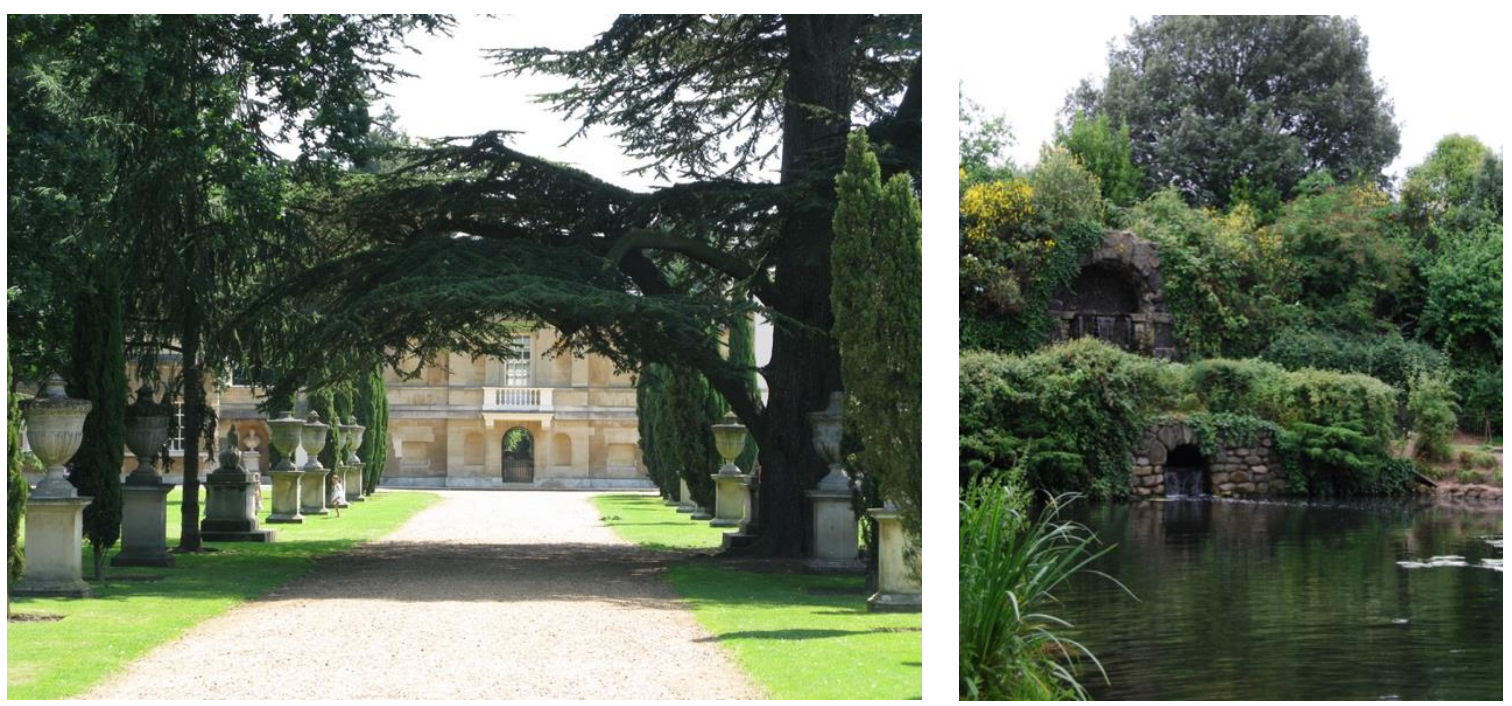

Fig. 5, 6. Chiswick Gardens. One of the first cases of the two aesthetic attitudes in one garden layout: classical axial layout and natural/romantic scenery. (England). Source: phot. author

Ryc. 5, 6. Ogrody Chiswick. Pierwszy przypadek zastosowania dwóch koncepcji estetycznych w jednym założeniu ogrodowym: klasyczny osiowy układ i sceneria naturalno-romantyczna. Źródło: fot. autor

The landscape garden at Stowe, designed later in the years after 1741 by the most creative garden artist of the time, Lancelot Brown (Capability Brown) is formed in a freer fashion. The palace complex with a developed plan was situated across the softly outlined main axis. Also, transverse to the axis is a watercourse with a sequence of quasi-natural ponds. The arrangement of alleys and paths was free and the plan lacks distinctive, geometric forms. The garden is a free-form, man-made physiographic space. It represents TYPE H1 composition, in which the subordinate individual arrangements do not stand out. 
How strong was the imperative to transform French gardens into English ones is evidenced by the fact that in 1774-1775 Louis XVI intended to arrange the gardens of Versailles in the English style. This time is considered the beginning of the landscape garden era in France. In the end, the king did not carry out this intention, introducing changes to make the maintenance of the baroque garden a little cheaper. (Thompson I., 2006, p. 186)

\section{GARDENS OF THE 19TH CENTURY}

England was a country where the growing wealth of the emerging middle class, the result of trade links with the Far East and South Asia played a large role in the importation and dissemination of imported exotic plants. At that time, almost every major estate had a conservatory, where they grew and experimented, perfecting familiar and new plant species. (Janick J., 2008. pp. 17-19) Gardens of the Royal Horticultural Society, where exhibitions were held, triggered an interest in ornamental plants and cultivations among the general populace.

The change of aesthetic canons in art in the 19th century, a result of the rise of the younger generation of artists, gradually changed the public's tastes. Landscape painting that has evolved since the eighteenth century, (Frazer L.Ch., 2017, pp. 4-14) became so valued and fashionable that polychromies on the walls of palaces began to depict fragments of natural landscapes instead of medallions, pilasters and colonnades. (Bardzinska-Bonenberg, 2008, p. 72.)

The nineteenth century also saw an increase in the number of people who acquired new or upgraded existing landholdings. The bourgeoisie, which emerged in the 18th century, already had great financial possibilities and similar aspirations. The new estates, due to the way of life and work of this group, were located on the outskirts of towns. The changes that occurred in the social, economic and technical spheres influenced the changes in the architecture and design of gardens.

Introducing native plant material into gardens and creating "idyllic" sections of them was a novelty introduced to gardens by Gertrude Jekyll, a painter and designer of many gardens in Europe and the United States (Bisgrove R., 1992). Working with Edwin Luytens, an architect and urban planner, they created a type of residential house blended into a garden full of native, as well as already acclimated, exotic plant species. Jekyll's compositions were in line with the atmosphere of the European Secession and the English Arts \& Crafts movement, whose creators used free, asymmetrical compositions and floral motifs.
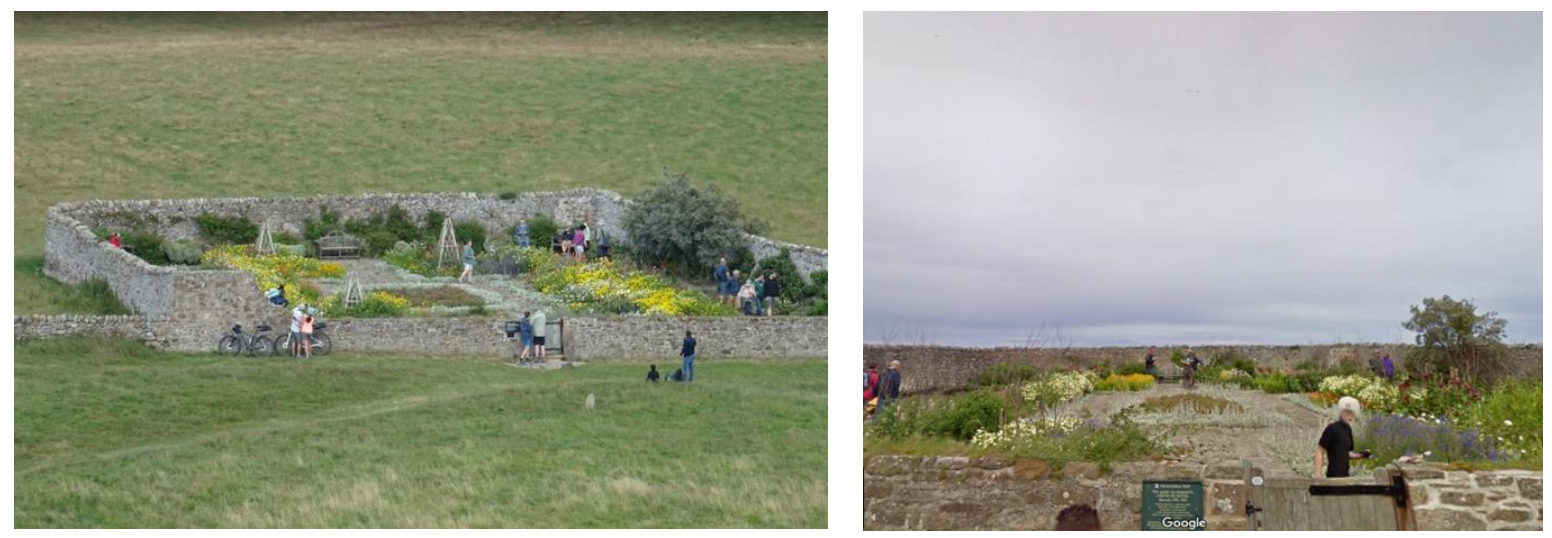

Fig. 7, 8. Holy Island (Scotland), Lindisfarne Castle Garden by Gertude Jekyll, for Edwin Lutyens in 1911, (reconstruction). Exposed to the North Sea winds this symmetrical flower (formerly a vegetable) garden is sheltered by the stone wall. Source: Google Earth. Phot. 08.2017., access 28.10.2021

Rys. 7, 8. Holy Island (Szkocja), Zamek Lindisfarne, Gertruda Jekyll dla Edwina Lutyensa w 1911. (rekonstrukcja). Eksponowany na wiatry Morza Północnego ten symetryczny kwiatowy ogród (uprzednio warzywny) jest chroniony kamiennym murem. Źródło: Google Earth. Fot. 08.2017., access 28.10.2021 
Gertrude Jekyll gardens combined a free arrangement of the whole with a separate rectangular or polygonal section of geometric design, surrounded by a pergola or wall planted with climbing plants. Jekyll called these spaces parterre: central, grassy planes on which were clusters of short plants. Surrounded by flat steps-flowerbeds where perennials of matched colours, heights and habitats grew. Beyond the "parterres" stretched a free-form park that flowed seamlessly into the open landscape. Another innovation Jekyll introduced was a front garden designed as a free interpretation of a "natural" access among local plants. The gardens that Jekyll designed are a new kind of space, which is described by solutions H2, H2, H3, H4, H5. The essence of Gertrude Jekyll's gardens was to inscribe them into a natural ecosystem through the selection of plants and the creation of space moving from a geometrically formed centre to an open landscape.

\section{CHANGES IN ATTITUDES TOWARDS GARDEN LAYOUTS IN THE $20^{\text {TH }}$ AND $21^{\text {ST }}$ CENTURIES}

In the 20th century, a cross-section of societies, ways of life, and the economics changed. Laws and regulations related to city planning and home building have changed.

New trends in garden design were set by architects of the first generation of modernists: Le Corbusier, Mies van der Roche, Alvar Aalto. There are clear differences in their conceptions related to the building.

Developing cities were enriched with garden city districts (Czyżewski A., 2009, pp. 45-49) In them, gardens around houses had significant limitations resulting from the urban arrangement. Borders between plots could disappear thanks to skilfully designed interiors of quarters. More and more small gardens became the subject of designs: semi-detached houses, terraced houses, detached houses on small plots required "centred" solutions. The growing importance of the home garden can be traced at successive Werkbund exhibitions. (Urbanik J., 2002, pp. 131-237) An example here are the projects of well-known German gardeners who realized model gardens for the housesexhibits of the Wroclaw WUWA in 1929. Also, competitions announced by Warsaw housing cooperatives in the interwar period provide information on this subject. (Rozbicka M., 2007, s.101-112) as well as designs of gardens in villa districts for Bydgoszcz. (Bręczewska-Kulesza D., Wysocka A., 2017, pp. 18, 67, 68, 163) (Fig. 9, 10) and Poznań.

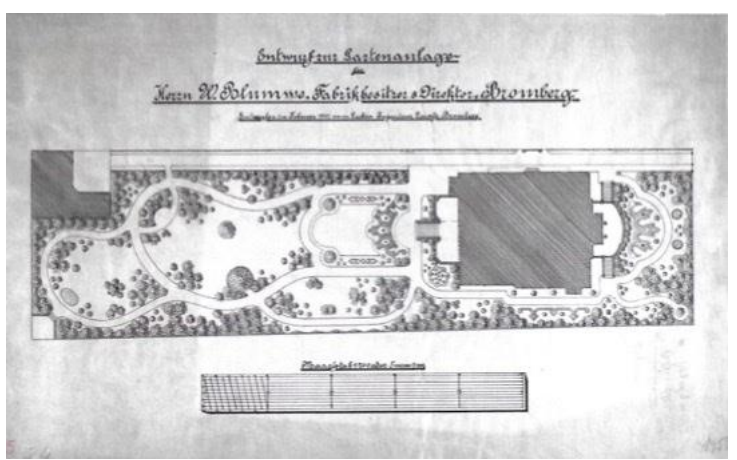

Fig. 9. Villa with a "landscape" garden, turn of the $19^{\text {th }}$ and $20^{\text {th }}$ c. Bydgoszcz, 50 Gdanska Str. Source: D. Bręczewska-Kulesza, A. Wysocka, 2017p. 67

Ryc. 9. Willa z ogrodem "krajobrazowym", przełom XIX i xx w., Bydgoszcz, ul. Gdańska 50, pracownia Larassów. Źródło: D. Bręczewska-Kulesza, A. Wysocka, 2017, s. 67

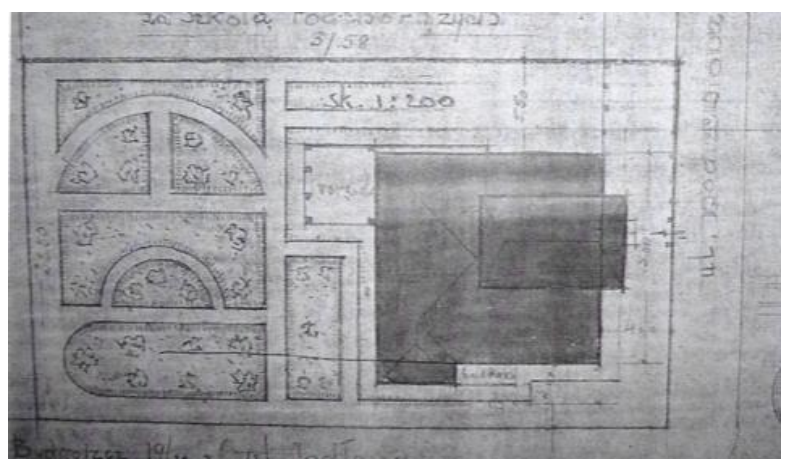

Fig. 10. J. Wojciechowski Villa, with modernistic Iplan of the garden, third decade of the $20^{\text {th }} \mathrm{c}$., Bydgoszcz Osiedle Leśne. Source: D. Bręczewska-Kulesza, A. Wysocka, 2017, p. 163

Ryc. 10. Willa J. Wojciechowskiego z modernistycznym planem ogrodu, trzecia dekada XX w. Bydgoszcz Osiedle Leśne. Źródło: D. Bręczewska-Kulesza, A. Wysocka, 2017, s. 163 
In comparison with the gardens designed in urban developments, villas were built on large plots.

Le Corbusier's Villa Savoye (1928-30) is an example of a solution where the solid of the villa contrasts with the background created for it. The villa is situated on an open plane of an oval lawn which is surrounded by trees. The surviving design documentation does not cover the entire garden. The surroundings of the unrealised Villa Meyer from 1925-26 were conceived differently. The building, traditionally with a roof garden, is surrounded by trees and shrubs planted right next to the walls. (Le Corbusier et Pierre Jeanneret, Oeuvre complete volume 1, 1910-1929.)

In this period, Villa Stein was designed, situated in a non-standard way in the depth of an elongated plot. A long driveway leads towards the trees planted on either side of the entrance, from where a direct view of the house facade opens up. The concept was only shown on the axonometry where the rest of the lot was not planned. (Modern Architecture Since 1900, Villa Stein). Likewise, the architect's urban visions with empty spaces focused on architecture ...magnificent game... of solids connected in light." (Le Corbusier, 1937)

Mies van der Rohe refined garden designs in the houses he built. Villa Tugendhat (1929-30) was designed for friends of the architect. The location on a sloping plot overlooking Brno dictated the design of the building and the garden. A narrow green belt with trees separated the plot from the street. On the garden side, directly at the lower terrace of the house the sloping semicircular bed was planted with low plants. The gentle slope below was occupied by a lawn with a lone tree. The tall greenery was designed so as not to obstruct the city skyline. (Villa Tugendhat Iconic Houses Org).

Villa Wolf, dating from 1927, is also located on the slope of the valley of the Lusatian Neisse in Gubin. The villa was destroyed in the last days of the war. It was faced with brick, with which the white stone retaining walls of the successive garden levels contrasted. Individual levels were occupied by low vegetation and single trees. (Mies van der Rohe Museum, Villa Wolf Gubin) The landscape of the valley with the river was included in the composition of the establishment.

The next buildings designed by Mies van der Rohe were two houses for two befriended families of industrialists. The Lange \& Esters ensemble (1927-29) was built in Krefeld, Germany, in the villa district of the city. The interior of the quarter with high trees was used to blur the boundaries of the plots. Geometric terraces, stairs, walls and flower beds were created directly next to the houses. Beyond the lawn began a park-like, tree-lined section that continued with the tall greenery of other plots. 23, 24. (Lange \& Esters House, WikiArquitectura)

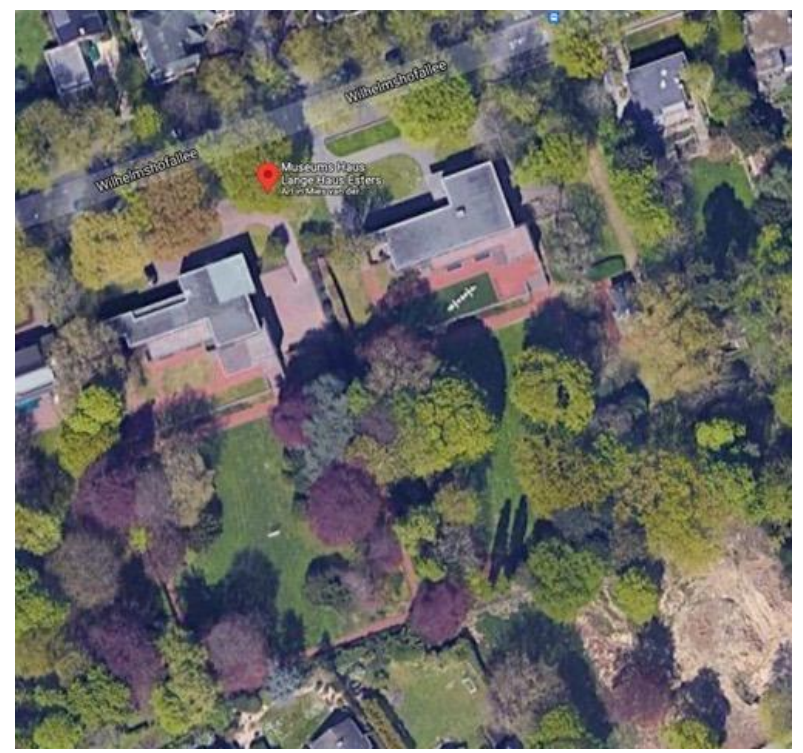

Fig. 11. Industrialists' Lange \& Esters houses in Krefeld (Germany) were pushed back from the street to gain good access by car and provide some privacy. At the back terraces proceeded into planes of lawns surrounded by trees. Source: Google Earth. Access 27.10.2021

Rys. 11. Domy przemysłowców Lange \& Esters w Krefeld (Niemcy) zostały odsunięte od ulicy, ułatwiając wjazd samochodom i zwiększając prywatność. Z tyłu tarasy przechodziły w płaszczyzny trawników otoczonych drzewami. Źródło: Google Earth. Dostęp 27.10.2021 
As with Villa Tugendhat, the street green belt was integrated into the garden by opening up the view into the interior of the quarter.

In Alvar Aalto's designs, landscape and nature have always been present as a reference point for architecture. Aalto's early houses do not stand out from the surrounding buildings; they are similarly blended into the greenery and often wooden. They are surrounded by fruit trees, shrubs, vines, grasses and flowers. Barely stone-paved access roads and walkways are located among them.

The Villa Mairea house-residence was built in 1938-39 for the Gullichsen couple, young Finnish industrialists. The boundary of the plot is invisible - the surrounding forest creates a clearing for the building with a projection close to the letter $\mathrm{L}$. The most important element of the open "yard" is an irregularly shaped swimming pool with vegetation on the edges.

In the post-war Villa Louis Carré in Bazoches-sur-Guyonne, France, built in 1956-61, the architect adopted similar principles. On a wooded, sloping hillside at the top of a clearing he placed a house that also served as an art gallery. Access, as in Villa Mairea led along a winding gravel road. The area next to the building has been landscaped with flat, grassy terraces, underpinned by wooden logs and mapping the course of the levels. (Alvar Aalto Fondation, Maison Louis Carré)

Creators of contemporary designed gardens looking for new solutions just like architects co-create the next trends in garden art.

John Brookes (1933-2018), one of Britain's best-known designers. He initially used modernist forms in his publications and professional practice and was considered the father of small modernist gardens in Europe (John Brookes, Garden Museum, Arts \& Culture). Over time, new motifs emerged in his work, as well as the term "stylizations" (Brookes J., 1991, Chapter 3) referring to the creation of gardens or parts of gardens inspired by history and other cultures. In Poland, Brookes renovated between 2005 and 2008 a historic landscape park in Kikol, where zoning of the space is visible. (Małecki J., 2018-21)

The phenomenon of freedom of style now exists in garden design just as it does in architecture. While in contemporary designed English gardens, both larger and small home gardens, the influence of Gertrude Jekyll and Brookes' concept can be seen, the French gardens, highly valued in the milieu and awarded, are definitely more geometric. Green material: shrubs, climbers, trees are subordinated to the composition of the whole and often formed. The legacy of the French Baroque is still noticeable.

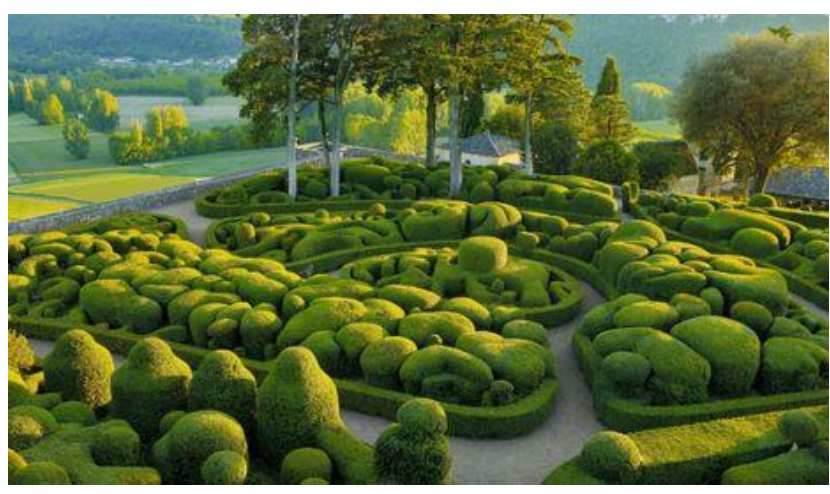

Fig. 12. Jacques Wirtz, Landscape garden, Belgium. Source: https://chicgardens.be/the-wirtz-gardens-prachtig-tafelboek-dat-jemoet-hebben/

Ryc. 12. Jacques Wirtz, Ogród krajobrazowy. Źródło: https://chicgardens.be/the-wirtz-gardens-prachtig-tafelboek-dat-jemoet-hebben/

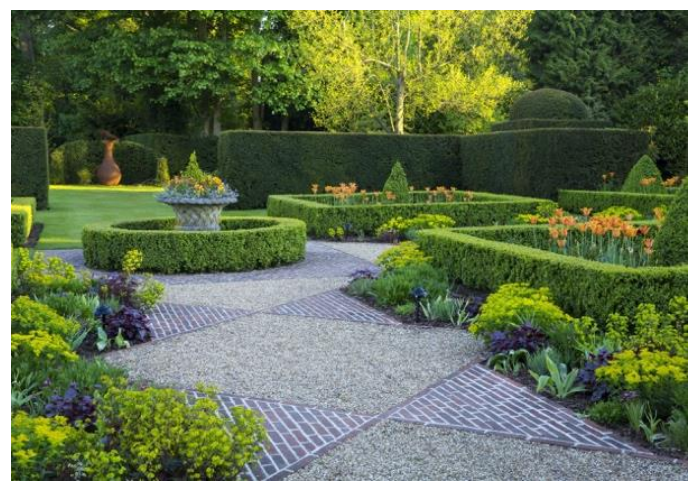

Fig. 13 Julie Toll. A sequency of interlinking garden interiors. Source: https://ngs.org.uk/julie-toll-themanor-house-ayot-st-lawrence/

Ryc. 13. Julie Toll. Sekwencja przenikających się wnętrz ogrodowych. Żródło: https://ngs.org.uk/julietoll-the-manor-house-ayot-st-lawrence/ 
This does not change the fact that contemporary gardens use motifs familiar from gardens around the world and from all eras, especially since the spread of the Internet. The gardens are complemented with contemporary sculptures, artifacts, mobiles, elements of abstract art, illusions most often magnifying or changing the perception of space. Compositions related to water (and usually) light constitute a separate chapter. The decisive factor has been the development of technology that makes it possible to make the use of the garden more attractive day and night.

As with architecture, there are dominant trends in garden design: in recent decades these have included: the mixing of green material with "artificial" fragments incorporated into the overall composition (Ecooutdoor), recently popular grass gardens and references to far-east garden art, (Great Gardens of the World, Wirtz International) the introduction of forms with intense colours. (Hobhouse 2007, pp. 450-453)

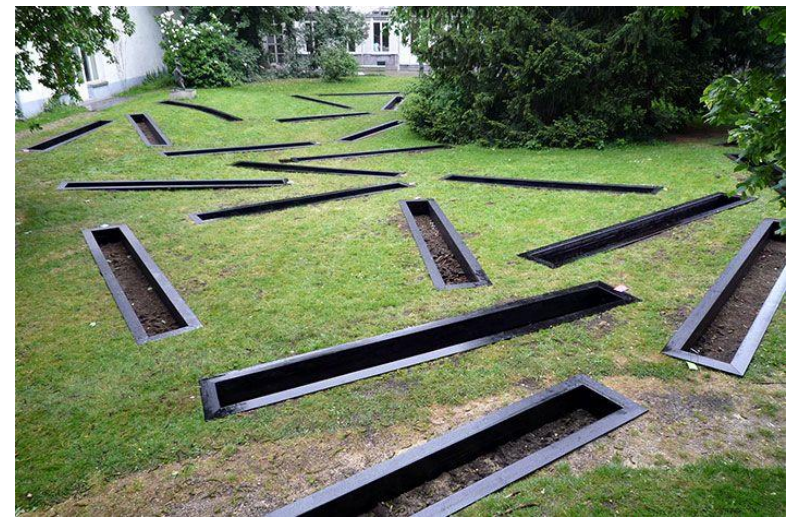

Fig. 14. Martha Schwartz, introduction of not-organic materials, direction towards abstract forms. Source:

https://pl.pinterest.com/pin/130885932904386700/

Ryc. 14. Martha Schwartz, wprowadzenie nieorganicznych materiałów i zwrot ku abstrakcyjnym formom. Źródło: https://pl.pinterest.com/pin/130885932904386700/

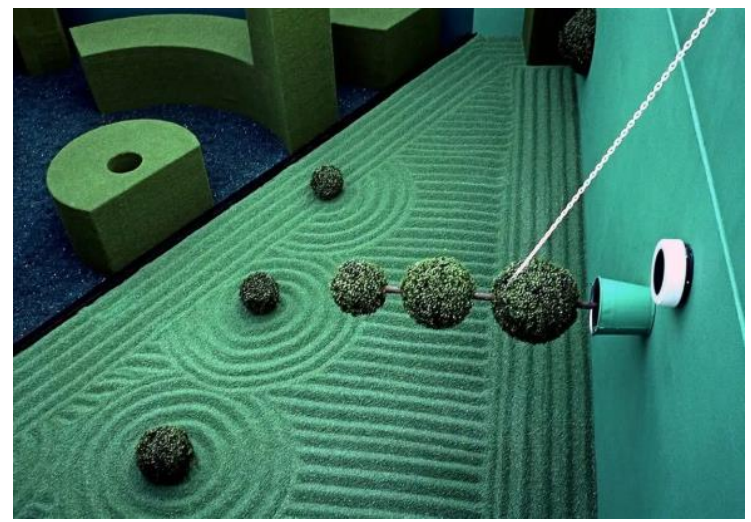

Fig. 15. Martha Schwartz, introduction of not-organic materials, abstract forms and colours Source:

https://msp.world/whitehead-institute-splice-gardencambridge-ma-usa/

Ryc. 15. Martha Schwartz, wprowadzenie kolorów, nieorganicznych materiałów i zwrot ku abstrakcyjnym formom, Żródło: https://pl.pinterest.com/pin/130885932904386700/

An overview of examples of solutions is provided by contemporary literature and press, including publications on websites. In the literature describing gardens today, it is difficult to find descriptions referring to the narrative sphere read by contemporaries. The gardens, especially the small ones, rarely contain motifs linking them programmatically to contemporary culture, art, or objectively important events. Sometimes the garden becomes a place to exhibit a collection of sculptures or other artifacts close to the owner, but it is not in itself a narrative relevant to its contemporaries such as the gardens of the Renaissance and Baroque.

Larger private gardens are often composed of several separate spaces, different in character; they contain fragments of miniaturised Baroque forms, beds in the spirit of Gertrude Jekyll; perspectives are created supported by mirrors on small surfaces... It is necessary to use partitions separating these "worlds".

A new phenomenon in contemporary garden design is the pro-ecological trend that limits interference and promotes flowery meadows and the introduction of melliferous plants. It is an element that links contemporary garden art with the cultural changes taking place, and perhaps a way to create a new direction in garden design.

Certainly, the two European gardens refer to the semiotic layer that historical gardens had, and the signs and symbols placed there refer to contemporary culture and engage the viewer intellectually. One of these, the Little Sparta Garden near Edinburgh (Bardzinska-Bonenberg T., Bonenberg A., 
Bonenberg W., 2021, pp. 172-180), the other is a garden that composer Krzysztof Penderecki (1933-2020) created in Lusławice near Tarnów (Bardzinska-Bonenberg T., Bonenberg A., Liu S., 2021, pp. 215-223). While the former is an authorial record of the reality experienced by lan Hamilton Finlay (1925-2006), the latter is a spatially reconstructed account of the events that took place in this peripheral corner of Small Poland region.

However, these are gardens belonging to establishments of a larger than average scale.

\section{SUMMARY}

The analysis of the composition of historical gardens and comparison of them with contemporary establishments leads to the following conclusions:

- from the 19th century onwards, the gardens associated with the residence are, with few exceptions, considerably smaller than in previous historical periods, but there are more of them

- the way of designing smaller spaces has changed: the conceptual coherence defined for the whole establishment now gives way to the fragmentation of space, both stylistic and functional; we can therefore speak of eclecticism

- gardens can be realized in different, sometimes exotic aesthetic conventions almost regardless of the climate in which they are created

- the consequence of the fragmentation of gardens is the introduction of different types of divisions for different, adjoining parts of the same garden

- gardens, even those designed by masters, are rarely a visible expression of the individual posture of the owner, they lack traces of his interests, passions and experience.

It follows from the above conclusions that the systematics of historical garden compositions presented in Table 1 showing their evolution from the simplest establishments (A1-A7) to many times complex arrangements (H1-H5) in the case of contemporary gardens must be intensified. Stylistically different parts of the gardens are separated by a variety of partitions and not connected by a layout of alleys. The number of spatial forms co-creating the garden include, as in the past, elements not only of plant material. Now they often affect the space also by unexpected colours, textures and light. The intensity of combining and overlapping of different forms pertains to the whole garden composition, not, as in large-scale developments - distant parts of a garden. Artificial light which was used for utility purposes, today creates nocturnal image of a garden. This is why analysis of contemporary gardens needs widening the research tools to enable further comparisons.

\section{SYSTEMATYKA ZAŁOŻEŃ HISTORYCZNYCH OGRODÓW JAKO ELEMENT WSPOMAGAJĄCY WSPÓŁCZESNE KONCEPCJE PROJEKTOWE}

\section{WSTĘP}

Celem badań było określenie czy i na ile zasady kompozycji ogrodów jakie znamy z historycznych założeń są dziś stosowane we współczesnych rozwiązaniach. Jaki jest zakres zmian i z czego one wynikają. Jest to kontynuacja pięcioletnich badań prowadzonych w polsko-chińskim zespole: Bardzinska-Bonenberg T., Bonenberg A., Bonenberg W., Liu Shoufang.

Zakres badań w części dotyczącej opracowania tabeli schematów kompozycyjnych ogrodów obejmuje literaturę dotyczącą ogrodów europejskich od czasów najdawniejszych, również tych, które powstały pod wpływem innych kultur, a które wpłynęły na późniejsze rozwiązania stosowane poza Półwyspem Iberyjskim. Część dotycząca współczesnych ogrodów (XX i XXI wiek) obejmuje omó- 
wienie europejskich koncepcji kreowane przez znanych architektów i architektów krajobrazu. Ta część pracy umożliwiła określenie $w$ jakim kierunku rozwija się współczesna sztuka ogrodowa związana z miejscami zamieszkania.

Metody badawcze zastosowane w pracy to analiza literatury i materiałów graficznych w tym inwentaryzacji założeń ogrodowych dawnych i współczesnych, syntetyczny zapis rozwiązań i uporządkowanie rezultatów w zestawieniu tabelarycznym. Istotnym elementem badań były obserwacje założeń ogrodowych na miejscu (dotyczy to Europy). Jest to metodologia zbliżona do stosowanej w naukach przyrodniczych, gdzie spektrum badań rozciąga się między światem materialnym, ożywionym i nieożywionym na różnych etapach jego rozwoju. Stąd konieczność stosowania specyficznych, dostosowanych do danego problemu badawczego zespołu narzędzi badawczych.

\section{EWOLUCJA ZASAD KOMPOZYCJI REZYDENCJONALNYCH OGRODÓW W ROZWOJU HISTORYCZNYM}

Opis rozwoju form ogrodowych z odniesieniami do powiązań ich z bryłami pałaców, a później domów znajduje się w opublikowanych rozdziałach Residences and Their Gardens i Garden - The Pursuit of Harmony in the Modern Times (Bardzinska-Bonenberg T., Bonenberg A., Bonenberg W., 2021 oraz Bardzinska-Bonenberg T., Bonenberg A., Liu S., 2021). Analiza zachodzących relacji przestrzennych i planów ogrodów wykazała, że elementy ich kompozycji powtarzają się w różnych epokach występując w różnych skalach i zajmując różne miejsca w hierarchii kompozycji całości. Pod tym kątem przeprowadzona została zamieszczona poniżej analiza tego zjawiska.

Niniejsza część opracowania skupia się na występujących dotąd schematach kompozycyjnych ogrodów od czasów dawnych do współczesności.

Tabela 1.: Zestawienie schematów kompozycji historycznych ogrodów

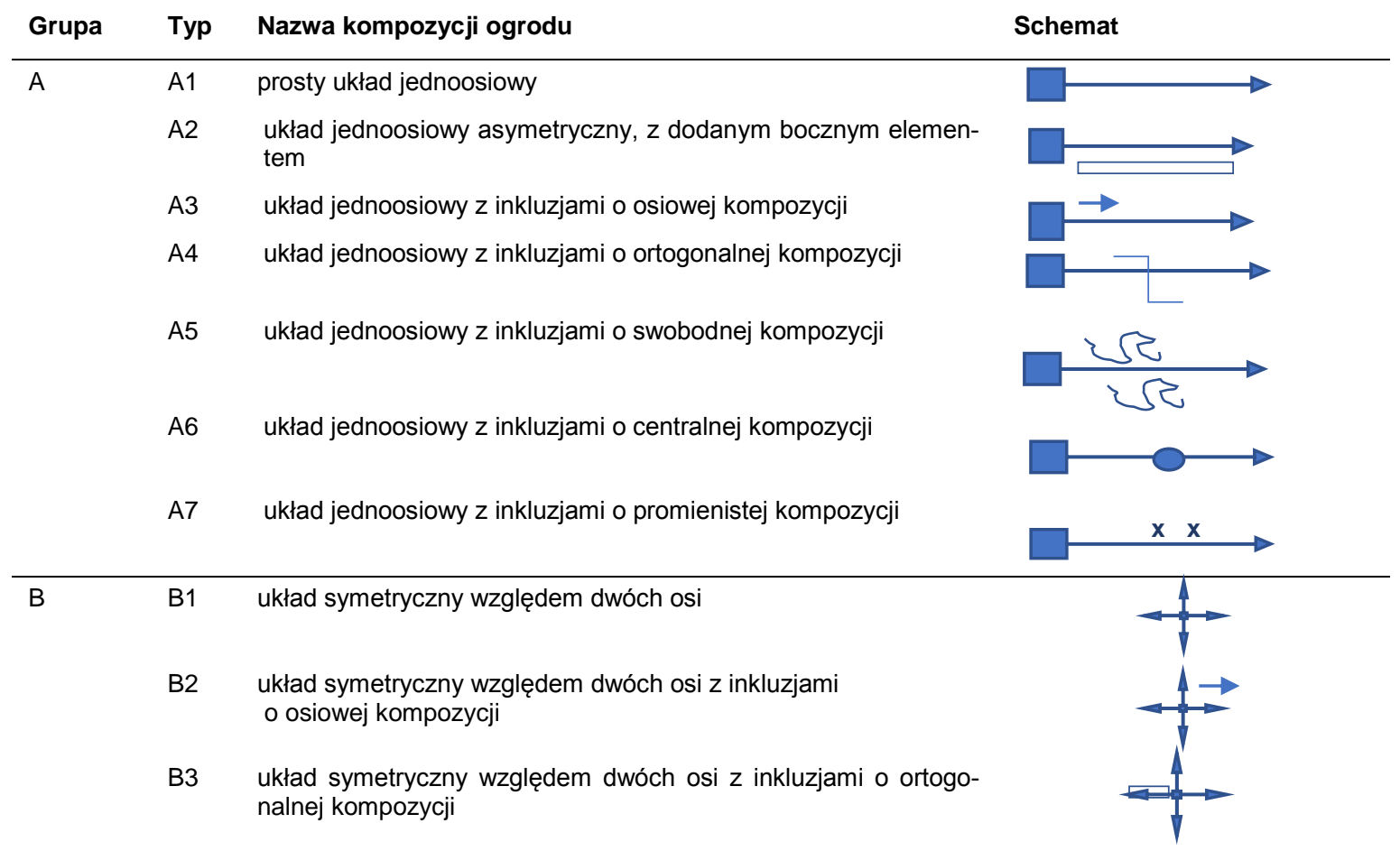




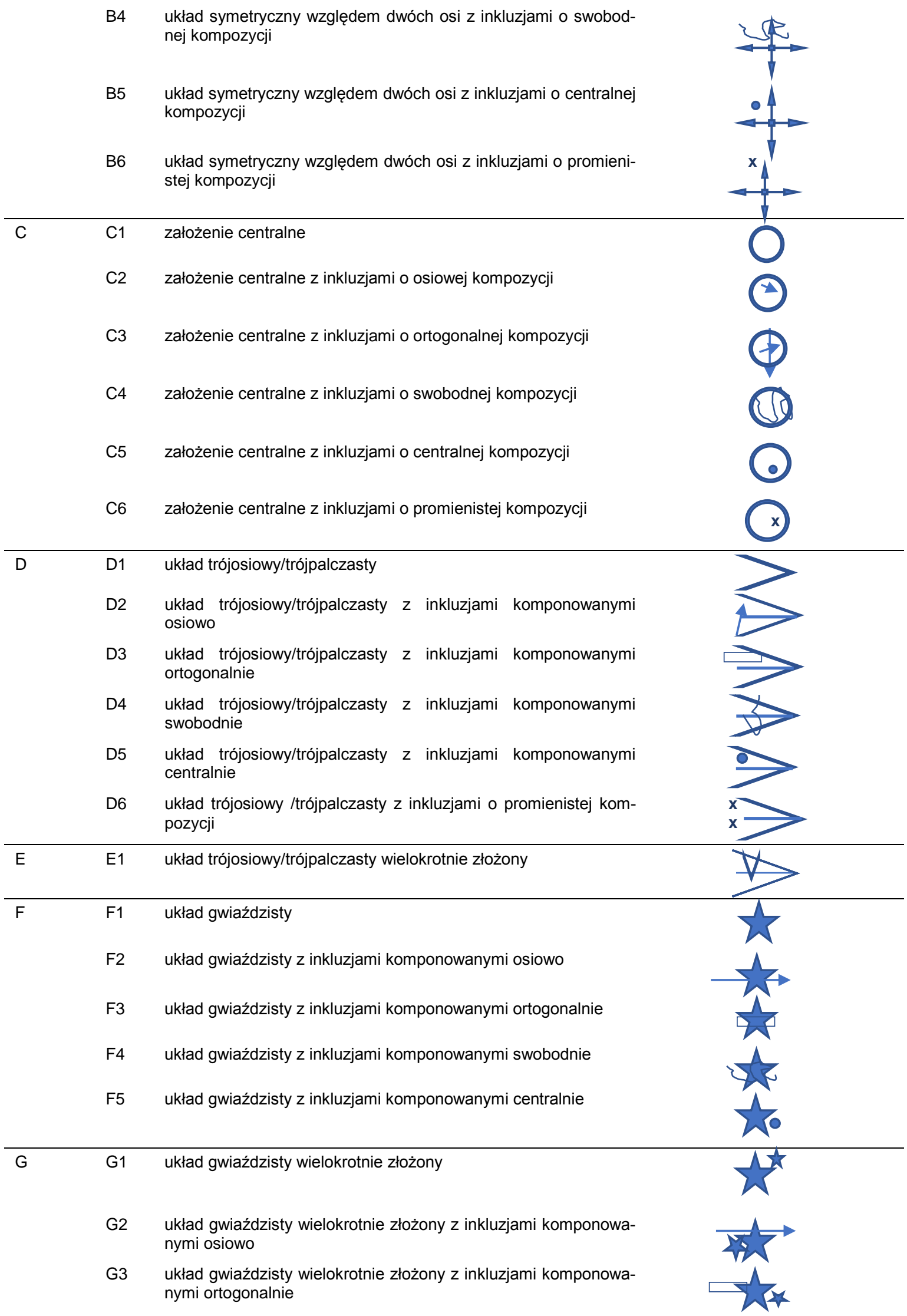




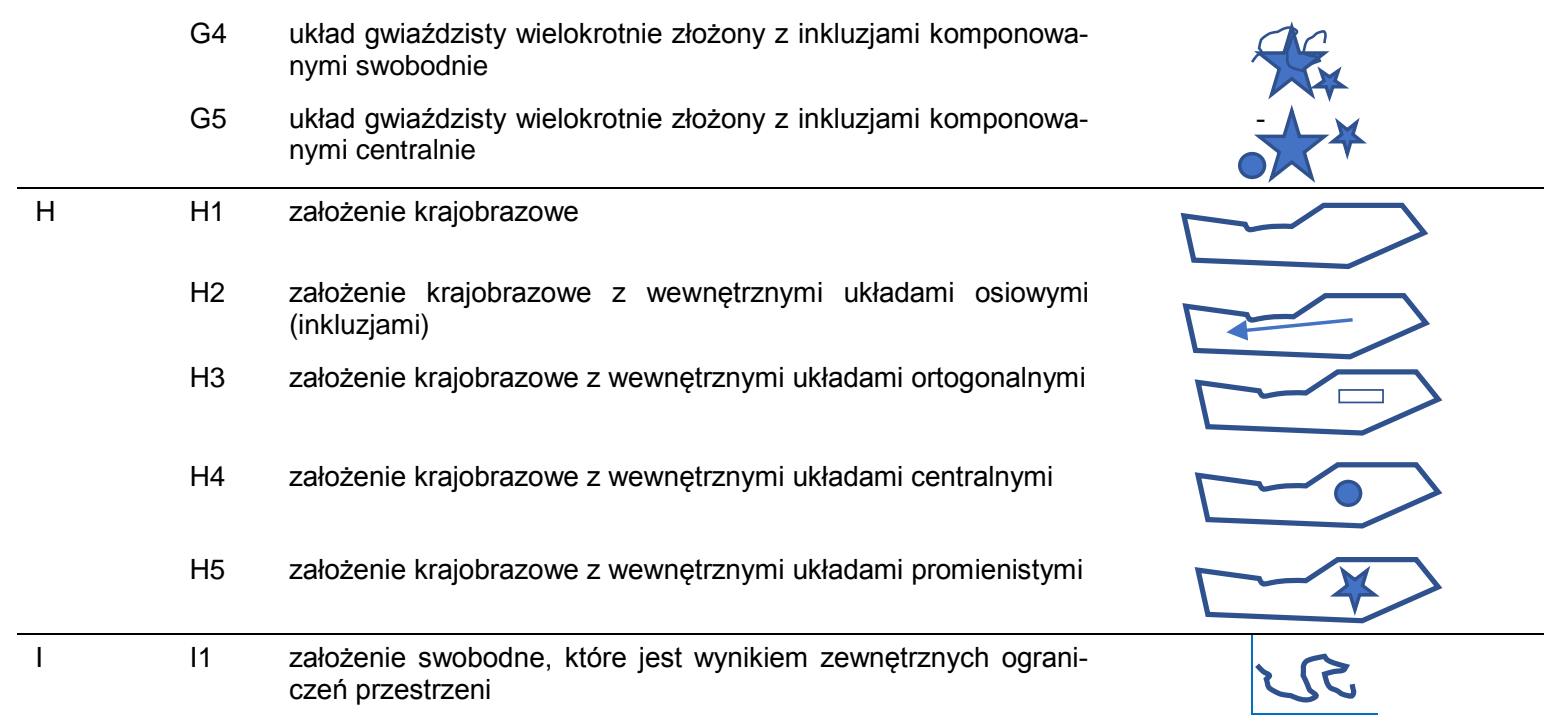

\section{STAROŻYTNOŚĆ}

Ogrody Starożytnego Egiptu były komponowane osiowo tak jak reprezentacyjna architektura, której towarzyszyły. Nie tylko całość założenia podporządkowana była jednej osi, ale także wyróżniające się $w$ tej całości fragmenty. Widać to wyraźnie na polichromii przedstawiającej rezydencję Senefera, dostojnika na dworze Amenhotepa II z XVIII dynastii, znajdującą się w jego grobowcu w Tebach. (Rice M., 1999, s. 12-13) Baseny z towarzyszącymi im altanami drzewami i szuwarami tworzyły w tym układzie osiowe kompozycje niższego rzędu. Całość reprezentuje TYP A3 ogrodu. W okresie panowania tej samej dynastii, w okresie religijnej schizmy i zmian we wszystkich niemal dziedzinach życia wybudowana została nowa stolica Tel-el-Amarna z pałacem faraona. Założenie pałacowo-ogrodowe komponowane było wzdłuż jednej osi, a towarzyszył mu podobny układ ogrodu z drzewami, i budynkami. Jest to TYP A2 ogrodu. W Depresji Fajum, zalanej wodami Nilu, powstało jezioro Moeris, gdzie na wyspie istniał teren polowań władców Średniego Państwa. (Manning J.G., 2003, s. 101-102) Utrzymywany był jako naturalny, z lasami łąkami i mokradłami. Był to najstarszy znany ogród TYPU H1.

Ogrodem świątynnym, komponowanym osiowo i tworzącym tarasowe, centralne najście od strony Nilu było przedpole świątyni Hatszepsut. Wiadomo, że osiowy układ założenia z drogą procesyjną podkreślały drzewa rozmieszczone po obu stronach na kolejnych skalnych tarasach. Misy wykute w skale, wypełnione nilowym namułem świadczą o istnieniu tarasowego założenia ogrodowego. Był to prawdopodobnie TYP A1.

Osiowo były kształtowane ogrody w atriach antycznych greckich domów. Nie wiadomo wiele na ich temat. Od wejścia do tablinum, przez impluwium przebiegała główna oś kompozycji.

Podobnie kształtowany był dom rzymski. Miał najczęściej kilka dziedzińców, perystyli, z basenami, otoczonych kolumnadą. Osiowa kompozycja była metodą podkreślania reprezentacyjnego charakteru budowli i związanych z nimi ogrodów. Jest to wyraźnie widoczne w kompleksach willowych należących do arystokratów rzymskich jak Villa Pliniusza reprezentująca TYP C2. Jedynie w wyjątkowych sytuacjach założenia o znacznej skali były swobodnie formowane jak w willi cesarza Hadriana w Tivoli pod Rzymem i willi cesarza Tyberiusza na Anacapri. (Majdecki L., 51-56) Tam jednak poszczególne elementy zespołu miały osiową, centralną i ortogonalną kompozycję. TYP H1-H5 


\section{4. ŚREDNIOWIECZE}

Ogrody klasztorne były uzupełnieniem zabudowy, wypełniając prostokątny lub kwadratowy wirydarz. Przecinały go ścieżki tworząc geometryczny układ o podkreślonym rzeźbą lub studnią punkcie centralnym. Reprezentują TYP B1 i C1 schematu ogrodu. Materiał roślinny wiązał się z symboliką religijną, a proporcje kościołów i zabudowy klasztornej miał uzasadnienie w Piśmie Świętym, mówiącym, że Pan Bóg stworzył świat według miary, liczby i wagi. (Katechizm Kościoła Katolickiego, s. 299)

Pozostałe klasztorne przestrzenie, jak wynika z zachowanych planów i przedstawień graficznych składały się z regularnie rozmieszczonych, prostokątnych lub kwadratowych grządek (TYP C4). (Majdecki L, s. 67-69) W ogrodach zamkowych wykorzystywano niewielkie wolne powierzchnie w fortecy lub międzymurza, a więc uzależnione od kształtu i oświetlenia przeznaczonych na nie zakątków. Ze względu na położenie na zamku, ogrody były przeznaczone dla władcy i dworu. Znane jako hortus conclusus, stanowiły często nieregularne, zielone wnętrza pomiędzy murami i zabudową i były skromnie wyposażone. Jest to TYP I1 ogrodu, o układzie swobodnym, wymuszonym przez ograniczenia terenu, na którym był sytuowany.

\section{CZASY NOWOŻYTNE}

Renesansowe rezydencje typu villa integrowały architekturę, zieleń, małą architekturę, a skala tych założeń rosła w miarę upływu czasu osiągając powierzchnie rzędu 4-5 ha.

Włoscy ogrodnicy, podobnie jak architekci, za moduł przyjęli kwadrat. Kwatery o tym kształcie mogły być obsadzone niską roślinnością tworząc parter lub boskiet jeśli wypełniały je drzewa. Ogród o osiowych i ortogonalnych podziałach był wyraźnie wydzielony z otaczającego krajobrazu (TYP A1 i A4). Partery były dzielone na mniejsze, geometryczne powierzchnie niskim żywopłotem i wypełniane ziołami i kwiatami. Na stokach formowano tarasy, a w najkorzystniejszych miejscach, wprowadzano widokowe otwarcia na dalekie perspektywy. We wielkoskalowych założeniach pojawiały się schody, rampy, a także labirynty z żywopłotów i kopce widokowe, wprowadzając wewnętrzne, niezależne ortogonalne i centralne formy (TYP A4 i A6), a także elementy wertykalne. Mniejsze ogrody były otoczone zewnętrznym murem lub żywopłotem, tworząc zamknięte wnętrze. W pewnej odległości od głównego założenia mógł znajdować się giardino semplici - ogród użytkowy i gospodarczy rezydencji. Miał geometryczne podziały, lecz nieokreślony kształt (TYP C4).

Renesansowe założenia ogrodowe zawdzięczały czytelność zastosowaniu osiom i geometrycznym formom używanym w nadrzędnych i podporządkowanych częściach kompozycji. (TYP A3)

Początek epoki baroku od 1660 roku wyznacza w sztuce ogrodowej budowa założenia wersalskiego, mimo, że wcześniej rozwiniętą formę barokowej rezydencji miał pałac Vaux-le Vicomte. W Anglii w tym samym czasie rozbudowano Hampton Court z barokowym wielkoskalowym założeniem, pod Wiedniem w 1696 zakończono budowę Pałacu Schönbrunn, a w Rosji w latach 1714-25 budowano carski pałac Peterhof. Wzorem władców arystokracja również wznosiła wspaniałe rezydencje. Ogrody, podobnie jak pałace były przeskalowane, składały się z niemal niezależnych części, a stosowane tam urządzenia wodne wykorzystywały najnowsze odkrycia fizyki i osiągnięcia techniki (Hobhouse P., 2007, s.156)

Poziome płaszczyzny, parterre, i pionowe ściany zieleni, rzeźby, oraz oprawa alei i basenów wodnych, kaskad i fontann była bogatsza niż w renesansie. Kwatery miały kształt wydłużonego prostokąta z zaplanowanymi „wycięciami”. Boskiety stały się niezbywalną częścią założeń barokowych, a w ich wnętrzach kryły się altany i obiekty poświęcone rozrywce. (Hobhouse P., 2007, p.156) Wspólna oś kompozycji obejmowała pałac i ogród. Odchodziły od niej ukośne aleje, tworząc układy trójpalczaste, które prowadziły ku zadrzewionym częściom ogrodu. Główna oś organizowała dynamiczną kompozycję trójosiowych i gwieździstych układów alej: TYP F1. Kompozycje kolejnych kwater wyczerpują niemal wszystkie geometryczne warianty: TYP F2, TYP F3, TYP F5. 
Trójpalczaste rozwiązania wykorzystywane były nie tylko w Wersalu TYP D1 układu był powszechnie stosowany w Europie. Kompozycje TYPU D2, D3, D5, D6 dominowały między innymi w założeniu pałacowo-ogrodowym Vaux-le-Vicomte.

Ostatnim z wielkich barokowych założeń rezydencjonalnych był pałac Peterhof w pobliżu Petersburga, letnia rezydencja cara Piotra II. Ogród zaplanowany wzdłuż wybrzeża Zatoki Fińskiej wybiega w nią promenadą i kanałem wodnym - elementami głównej osi całego założenia. Osi tej podporządkowana została bryła pałacu i drugi ogród od strony głównego wejścia (TYP A1-A4, A6-A7). Przy położonym na skarpie pałacu, na poprzecznej osi (TYP A4) powstała kaskada wodna ze stu czterdziestu fontann. Po jej dwóch stronach aleje tworzą niemal symetryczne, gwiaździste, układy (TYP A7). Motyw dominacji nad lądem, ale również nad morzem jest tu tak samo czytelny jak w innych założeniach budowanych dla europejskich monarchów tamtego czasu.

Przeskalowanie założeń rezydencjonalnych w epoce baroku zmieniło ich odbiór i strukturę. Ogromne przestrzenie zostały przypisane zróżnicowanym funkcjom, a każda z nich była inaczej aranżowana. Zastosowanie wydłużonych parterów, a przede wszystkim alei krzyżujących się lub rozbiegających pod kątem ostrym znakomicie zaburzyło możliwość całościowego odczytania układu ogrodów przez użytkowników (TYP G1).

\section{REGULARNE I SWOBODNE UKŁADY XVIII-WIECZNYCH OGRODÓW}

Antoine-Joseph Dezallier d'Argenville w drugim wydaniu dzieła La théorie et la pratique du jardinage w 1713 roku wprowadził pojęcie naturalności w ogrodzie. Rozumiał przez to stosowanie trawników na ukształtowanych płaszczyznach, rampach i schodach, pnącza i trejaże. (Lauterbach I., 2018) Zbiegło się to $z$ nowymi tendencjami w sztuce: porzucenie przez malarzy pracy $w$ atelier i wyjście w plener pierwszych artystów dało początek zwrotowi ku malarstwu pejzażowemu. We Francji byli to Claude Lorrain (1600-1682), Nicolas Poussin (1594-1665), w Anglii, Sir Joshua Reynolds (1723-1792), Thomas Gainsborough (1727-1788), później John Constable (1776-1837). W 1709, malarz i późniejszy architekt i projektant ogrodów, William Kent (1685-1748) po pobycie we Włoszech, wypowiedzią: "All gardening is landscape painting" określił nowy kierunek kształtowania ogrodów angielskich. (Hunt J. D., Dixon J., 2003.) Grand Tour, którą odbywali przedstawiciele wyższych sfer i artyści wpłynęła na zmianę gustów: piękno europejskich, zwłaszcza włoskich krajobrazów powodowało zrozumienie malarstwa pejzażowego, a także nowe oczekiwania w stosunku do ogrodów. Kontakty handlowe $z$ dalekowschodnimi i południowoazjatyckimi krajami spowodowały napływ przedmiotów reprezentujących inną estetykę. Działania ludzi pokazywano na tle krajobrazu i roślinności.

Techniczną stronę realizacji ogrodów krajobrazowych XVIII w. wymagających dużych robót ziemnych umożliwiała wiedza inżynierska, rozwinięta na potrzeby armii. Znany projekt ogrodu Chiswick autorstwa Wiliama Kenta i Lorda Burlington (budowany od 1729) stworzony po ich „włoskiej” podróży jest przykładem przenikania się dwóch koncepcji: osiowego i krajobrazowego kształtowania ogrodu. Przeważa jednak układ osiowy: główną aleję zamyka symetryczny Chiswick House, a część ogrodowa skomponowana jest na trójpalczastym układzie alei. (TYP D1). Pomiędzy nimi oraz na północ i południe od nich mniejsze sekcje ogrodu komponowane są różnie: centralnie, ortogonalnie, gwiaździście, swobodnie (TYPY D4, D5, D6) stanowiąc o dość nieformalnym rozdysponowaniu tej części ogrodu. Inspiracje włoskim pejzażem są motywem wiodącym w całości założenia głównie za sprawą doboru roślinności.

Krajobrazowy ogród w Stowe, zaprojektowany później, bo w latach po 1741 przez najbardziej kreatywnego w tamtych czasach artystę-ogrodnika, Lancelota Browna (Capability Browna) jest rozwiązany swobodniej. Zespół pałacowy o rozbudowanym rzucie usytuowany został w poprzek miękko poprowadzonej osi głównej. Również poprzecznie do osi jest przebiega ciek wodny z sekwencją niby-naturalnych stawów. Układ alej i ścieżek był swobodny, a na planie brak wyróżniających się, zgeometryzowanych form. Ogród stanowi swobodną, przestrzeń o fizjografii ukształtowanej przez człowieka. Reprezentuje TYP H1 kompozycji, w której nie wyróżniają się podrzędne, indywidualne układy. 
O tym jak silny był imperatyw przekształcania ogrodów francuskich w angielskie świadczy fakt, że w latach 1774-1775 Ludwik XVI miał zamiar zaaranżować ogród wersalski w stylu angielskim. Ten czas uważany jest za początek epoki ogrodów krajobrazowych we Francji. Ostatecznie król nie zrealizował tego zamiaru, wprowadzając zmiany obniżające koszt utrzymania ogrodu. (Thompson I., 2006, s. 186)

\section{OGRODY XIX WIEKU}

Anglia była krajem, gdzie rosnące bogactwo powstającej klasy średniej, wynik handlowych powiązań z Dalekim Wschodem i Azją Południową odegrał dużą rolę w sprowadzaniu i upowszechnianiu przywożonych egzotycznych roślin. W tym czasie niemal każda większa posiadłość miała oranżerię, gdzie hodowano i eksperymentowano, doskonaląc znane i nowe gatunki roślin. (Janick J., 2008. s. 17-19) Ogrody Royal Horticultural Society, gdzie organizowane były wystawy spowodowały zainteresowanie roślinami ozdobnymi i uprawami wśród szerokiego społeczeństwa.

Zmiana kanonów estetycznych w sztuce w XIX wieku, wynik dojścia do głosu młodego pokolenia twórców, stopniowo zmieniała gusty publiczności. Malarstwo pejzażowe, które od XVIII w. ewoluowało, (Frazer L.Ch., 2017, pp. 4-14) stało się tak cenione i modne, że polichromie na ścianach pałaców w miejsce medalionów, pilastrów i kolumnad zaczęły przedstawiać fragmenty naturalnego pejzażu. (Bardzińska-Bonenberg, 2008, s. 72.)

W XIX wieku powiększyła się też grupa ludzi, którzy nabywali nowe lub modernizowali istniejące posiadłości ziemskie. Powstała w XVIII wieku warstwa burżuazji miała już duże możliwości finansowe i podobne aspiracje. Nowe majątki, ze względu na sposób życia i pracy tej grupy były sytuowane na obrzeżach miast. Zmiany jakie następowały w sferze społecznej, gospodarki i techniki wpłynęły na zmiany w architekturze i projektowaniu ogrodów.

Wprowadzanie do ogrodów rodzimego materiału roślinnego i tworzenie ich „sielskich” fragmentów było nowością, którą wprowadziła do ogrodów Gertruda Jekyll, malarka i projektantka wielu ogrodów w Europie i Stanach Zjednoczonych (Bisgrove R., 1992) Współpracując z Edwinem Luytensem, architektem i urbanistą stworzyli typ domu mieszkalnego wtopionego w ogród pełen rodzimych, a także już aklimatyzowanych, egzotycznych gatunków roślin. Kompozycje Jekyll wpisywały się w atmosferę europejskiej Secesji i angielskiego ruchu Arts \& Crafts, których twórcy operowali swobodnymi, asymetrycznymi kompozycjami oraz motywami roślinnym.

Ogrody Jekyll łączyły swobodny układ całości z wydzieloną prostokątną lub wieloboczną sekcją o geometrycznym rysunku, otoczoną pergolą lub murem obsadzonymi pnączami. Jekyll nazwała te przestrzenie parterre: centralne, trawiaste płaszczyzny, na których znajdowały się klomby niskich roślin. Otoczone były płaskimi stopniami-rabatami, gdzie rosły byliny o dobranych kolorach, wysokościach i pokrojach. Poza „parterem” rozciągał się swobodnie kształtowany park, który płynnie przechodził w otwarty krajobraz. Inną nowością, którą wprowadziła Jekyll był ogród przed domem projektowany jako swobodna interpretacja „naturalnego" dojścia wśród lokalnych roślin. Ogrody, które projektowała to nowy rodzaj przestrzeni, którą opisują rozwiązania H2, H2, H3, H4, H5. Istotą ogrodów Gertrudy Jekyll było wpisywanie ich w naturalny ekosystem przez dobór roślin i tworzenie przestrzeni przechodzącej od geometrycznie formowanego centrum ku otwartemu krajobrazowi.

\section{ZMIANY W POSTRZEGANIU ZAŁOŻEŃ OGRODOWYCH W XX I XXI WIEKU}

W XX wieku zmienił się przekrój społeczeństw, sposób życia, gospodarka. Zmieniło się prawo i regulacje związane z planowaniem miast i budową domów.

Nowe trendy w projektowaniu ogrodów wyznaczali architekci pierwszego pokolenia modernistów: Le Corbusier, Mies van der Roche, Alvar Aalto. W ich koncepcjach widać wyraźne różnice.

Rozwijające się miasta wzbogacały się o dzielnice typu garden city (Czyżewski A., 2009, s.45-49) W nich ogrody wkoło domów miały istotne ograniczenia wynikające z układu urbanistycznego. Granice między działkami mogły znikać dzięki umiejętnie zaprojektowanym wnętrzom kwartałów. 
Coraz więcej małych ogrodów stawało się przedmiotem projektów: domy-bliźniaki, domy szeregowe, domy wolnostojące na małych działkach wymagały rozwiązań „dośrodkowych”. Wzrost znaczenia przydomowego ogrodu można śledzić na kolejnych wystawach Werkbundu. (Urbanik J., 1998, s. 135-138) Przykładem mogą być tu projekty znanych niemieckich ogrodników realizujących wzorcowe ogrody dla domów-eksponatów wrocławskiej WUW-y z 1929 roku. Również konkursy ogłaszane przez warszawskie spółdzielnie mieszkaniowe dwudziestolecia międzywojennego dostarczają informacji na ten temat. (Rozbicka M., 2007, s. 101-112), podobnie jak projekty ogrodów w dzielnicach willowych dla Bydgoszczy (Bręczewska-Kulesza D., Wysocka A., 2017, s. 18, 67, 68, 163) i Poznania.

Oprócz ogrodów projektowanych w miejskiej zabudowie powstawały wille na obszernych działkach.

Przykładem rozwiązania, gdzie bryła willi kontrastuje ze stworzonym dla niej tłem jest Villa Savoye (1928-30) Le Corbusiera, usytuowana na otwartej płaszczyźnie owalnego trawnika, który otaczają drzewa. Zachowana dokumentacja projektowa nie obejmuje całego ogrodu. Inaczej pomyślane było otoczenie niezrealizowanej Villi Meyer z lat 1925-26. Budynek, tradycyjnie z ogrodem na dachu, otoczony jest drzewami i krzewami sadzonymi tuż przy ścianach. (Le Corbusier et Pierre Jeanneret, Oeuvre complète, volume1, 1910-1929.) W tym okresie zaprojektowana była Villa Stein usytuowana w niestandardowy sposób w głębi wydłużonej działki. Długi podjazd prowadzi ku drzewom zasadzonym po obu stronach wjazdu, skąd otwiera się bezpośredni widok na fasadę domu. Koncepcja została pokazana tylko na aksonometrii, na której pozostała część działki nie była zaplanowana. (Modern Architecture Since 1900, Villa Stein). Podobnie, urbanistyczne wizje architekta z pustymi przestrzeniami skupione były na architekturze ...wspaniałej grze ... brył połączonych w świetle". (Le Corbusier, 1937)

Mies van der Rohe w realizowanych przez siebie domach dopracowywał projekty ogrodów. Villa Tugendhat (1929-30) została zaprojektowana dla przyjaciół architekta. Usytuowanie na spadzistej działce z widokiem na Brno narzuciło sposób kształtowania budynku i ogrodu. Od strony ulicy działkę oddzielał wąski pas zieleni z drzewami. Od strony ogrodu, bezpośrednio przy dolnym tarasie domu nachylona półkolista skarpa była obsadzona niskimi roślinami. Łagodny spadek poniżej zajmował trawnik z samotnym drzewem. Wysoka zieleń została zaprojektowana tak, by nie zasłaniać panoramy miasta. (Villa Tugendhat Iconic Houses Org). Również Willa Wolf, z 1927 roku, położona jest na skarpie doliny Nysy Łużyckiej w Gubinie. Willa została zniszczona w ostatnich dniach wojny. Licowana była cegłą, z którą kontrastowały białe, kamienne murki oporowe kolejnych poziomów ogrodu. Poszczególne tarasy zajmowała niska roślinność i pojedyncze drzewa. (Mies van der Rohe Museum, Villa Wolf Gubin) Krajobraz doliny z rzeką został włączony do kompozycji założenia.

Kolejnymi, zaprojektowanymi przez Miesa van der Rohe budynkami były dwa domy dla dwóch rodzin przyjaźniących się przemysłowców. Zespół domów Lange \& Esters (1927-29) powstał w Krefeld (Niemcy), w dzielnicy willowej miasta. Wnętrze kwartału z wysoką zielenią zostało wykorzystane by zatrzeć granice działek. Bezpośrednio przy domach powstały geometryczne tarasy, schody, murki i klomby z kwiatami. Za trawnikiem zaczynała się parkowa, obsadzona drzewami część, której kontynuacją była wysoka zieleń innych działek. 23, 24. (Lange \& Esters House, WikiArquitectura) Podobnie jak w przypadku Villi Tugendhat, pas zieleni ulicznej został zintegrowany z ogrodem przez otwarcie wglądu do wnętrza kwartału zabudowy.

W projektach Alvara Aalto krajobraz i przyroda zawsze były obecne jako punkt odniesienia dla architektury. Wczesne domy Aalto nie wyróżniają się z otaczającej zabudowy, są podobnie wtopione w zieleń i często drewniane. Otaczają je drzewa owocowe, krzewy, pnącza, trawy i kwiaty. Wśród nich prowadzą ledwo utwardzone kamieniami dojazdy i dojścia. Villa Mairea, domrezydencja została zbudowana w latach 1938-39 dla małżeństwa Gullichsen, młodych fińskich przemysłowców. Granica działki jest niewidoczna - otaczający las tworzy polanę dla budynku o rzucie zbliżonym do litery L. Najważniejszym elementem otwartego „podwórza” jest basen o nieregularnym kształcie z roślinnością na brzegach. W powojennej, zbudowanej w latach 1956-61 Willi Louis Carré w Bazoches-sur-Guyonne we Francji, architekt przyjął podobne założenia. Na lesistym, spadzistym zboczu u szczytu polany umieścił dom pełniący także funkcję galerii sztuki. Dojazd, podobnie jak w Villa Mairea poprowadził krętą, żwirową drogą. Teren przy budynku został 
ukształtowany płaskimi, trawiastymi tarasami, podbudowanymi drewnianymi balami i odwzorowującymi przebieg poziomnic. (Alvar Aalto Fondation, Maison Louis Carré)

Twórcy współcześnie projektowanych ogrodów poszukując nowych rozwiązań tak jak architekci współtworzą kolejne trendy w sztuce ogrodowej.

John Brookes (1933-2018), jeden z najbardziej znanych brytyjskich projektantów. W swoich publikacjach i praktyce zawodowej stosował początkowo modernistyczne formy i był uznawany za ojca niewielkich ogrodów modernistycznych w Europie (John Brookes, Garden Museum, Arts \& Culture) Z biegiem czasu w jego twórczości pojawiły się nowe motywy i termin „stylizacje” (Brookes J., 1991, Chapter 3), odnoszący się do kreowania ogrodów lub ich części inspirowanych historią i innymi kulturami. W Polsce Brookes rewaloryzował w latach 2005-2008 zabytkowy, krajobrazowy park w Kikole, gdzie strefowanie przestrzeni jest wyraźne. (Małecki J., 2018-21)

Zjawisko dowolności stylowej istnieje obecnie w projektowaniu ogrodów podobnie jak ma to miejsce $w$ architekturze. O ile we współcześnie projektowanych angielskich ogrodach, zarówno większych, jak i przydomowych widać wpływ koncepcji Gertrudy Jekyll i Brookes'a, to wysoko oceniane w środowisku i nagradzane ogrody francuskie są zdecydowanie bardziej geometryczne. Materiał zielony: krzewy, pnącza, drzewa podporządkowane są kompozycji całości i często formowane. Dziedzictwo francuskiego baroku jest wciąż zauważalne.

Nie zmienia to faktu, że we współczesnych ogrodach stosowane są motywy znane z ogrodów całego świata i wszystkich epok, zwłaszcza od czasu upowszechnienia się internetu. Ogrody uzupełniane są współczesnymi rzeźbami, artefaktami, mobilami, elementami sztuki abstrakcyjnej, iluzjami najczęściej powiększającymi lub zmieniającymi odbiór przestrzeni. Osobną grupę stanowią kompozycje związane z wodą (i zazwyczaj) światłem. Decydujący stał się rozwój techniki umożliwiającej uatrakcyjnienie korzystania z ogrodu w dzień i w nocy.

Tak jak w przypadku architektury w projektowaniu ogrodów pojawiają się dominujące tendencje: w ostatnich dekadach są to: mieszanie materiału zielonego ze „sztucznymi” fragmentami wpisanymi w całość kompozycji (firma ecooutdoor), popularne ostatnio ogrody traw i nawiązywanie do dalekowschodniej sztuki ogrodowej, (Great Gardens of the World, Wirtz International) wprowadzanie form o intensywnych kolorach. (Hobhouse 2007, pp. 450-453) Przegląd przykładów najnowszych rozwiązań przynosi współczesna literatura i prasa, w tym platformy internetowe.

W literaturze przedmiotu opisującej ogrody trudno dziś jest znaleźć realizacje posiadające sferę narracyjną odczytywaną przez współczesnych. Ogrody, zwłaszcza te niewielkie, rzadko zawierają motywy wiążące je programowo ze współczesną kulturą, sztuką, zdarzeniami obiektywnie ważnymi. Czasem ogród staje się miejscem ekspozycji kolekcji rzeźb lub innych artefaktów bliskich właścicielowi, sam w sobie nie jest jednak narracją istotną dla współczesnych jaką były $\mathrm{m}$. in. ogrody renesansu i baroku.

Większe prywatne ogrody są często komponowane z kilku odrębnych, różnych w charakterze przestrzeni, znajdują się $w$ nich fragmenty zminiaturyzowanych rozwiązań barokowych, rabat w duchu Gertrudy Jekyll, tworzone są perspektywy wspomagane lustrami na małych powierzchniach... Koniecznym rozwiązaniem jest stosowanie przegród wydzielających te „światy”. Nowym zjawiskiem w projektowaniu współczesnych ogrodów jest nurt proekologiczny ograniczający ingerencje i promujący kwietne łąki i introdukcję miododajnych roślin. Jest to element wiążący współczesną sztukę ogrodową z zachodzącymi zmianami kulturowymi i być może droga do stworzenia nowego kierunku w projektowaniu ogrodów.

Z pewnością dwa współczesne, europejskie ogrody nawiązują do semiotycznej warstwy jaką miały ogrody historyczne, a znaki i symbole jakie tam umieszczono odnoszą się do dzisiejszej kultury i angażują odbiorcę intelektualnie. Jeden z nich, to ogród Little Sparta pod Edynburgiem (Bardzinska-Bonenberg T., Bonenberg A., Bonenberg W., 2021, pp. 172-180), drugi jest ogrodem jaki stworzył kompozytor Krzysztof Penderecki (1933-2020) w Lusławicach niedaleko Tarnowa (BardzinskaBonenberg T., Bonenberg A., Liu S., 2021, pp. 215-223) O ile pierwszy jest autorskim zapisem rzeczywistości przeżytej przez lana Hamiltona Finlay’a, drugi jest zrekonstruowaną w przestrzeni opowieścią o wydarzeniach jakie miały miejsce w tym peryferyjnym zakątku Małopolski. 
Są to jednak ogrody należące do założeń o większej skali niż przeciętna.

\section{WNIOSKI}

Analiza kompozycji ogrodów historycznych i porównanie ich ze współczesnymi założeniami prowadzi do następujących wniosków:

- począwszy od XIX w. ogrody związane z miejscem zamieszkania są z niewielkimi wyjątkami zdecydowanie mniejsze niż w poprzednich okresach historycznych, jest ich jednak więcej,

- zmienił się sposób projektowania mniejszych przestrzeni: spójność koncepcyjna określona dla całości założenia ustępuje dziś fragmentacji przestrzeni zarówno stylistycznej jak funkcjonalnej; można więc mówić o eklektyzmie,

- ogrody są realizowane w różnych, czasem egzotycznych konwencjach estetycznych, niemal niezależnie od klimatu, w którym powstają,

- konsekwencją fragmentacji ogrodów jest wprowadzanie różnych typów rozwiązań dla poszczególnych, sąsiadujących części tego samego ogrodu

- ogrody, nawet te, projektowane przez mistrzów rzadko są widomym wyrazem indywidualnej postawy właściciela, brak im śladów jego zainteresowań, pasji i przeżyć.

- rozwiązania tworzone w XX i XXI wieku, dały podstawę do podstawę do potwierdzenia $z$ jednej strony nieprzemijalności podstawowych elementów kompozycji ogrodów, a z drugiej istnienia zupełnie nowych elementów, które determinują odbiór przestrzeni ogrodu związanego $\mathrm{z}$ domem/rezydencją.

Z powyższych wniosków wynika, że przedstawiona w Tabeli 1. systematyka kompozycji historycznych ogrodów, wykazująca ich ewolucję od najprostszych założeń (A1-A7) do wielokrotnie złożonych układów (H1-H5) w przypadku ogrodów współczesnych musi ulec rozbudowie. Odmienne stylistycznie części ogrodów są rozdzielane przegrodami o różnym charakterze, a nie łączone są systemami alej. Elementy przestrzenne współtworzące ogród obejmują, jak dawniej, nie tylko materiał roślinny. Teraz często oddziałują one na przestrzeń również przez nieoczekiwane kolory, faktury i światło. Intensywność łączenia i nakładania się różnych form dotyczy całości ogrodu, a nie jak we wielkoskalowych założeniach - odległych jego części. Sztuczne oświetlenie, które pełniło funkcję utylitarną obecnie współtworzy nocny obraz ogrodu. Dlatego analiza współczesnych założeń ogrodowych wymaga rozbudowy aparatu badawczego, który umożliwi dalsze porównania.

\section{BIBLIOGRAPHY}

Bardzinska-Bonenberg T., Założenie pałacowo-parkowe Czerniejewo. Poznań, Wydział Architektury Politechniki Poznańskiej, 2008.

Bardzinska-Bonenberg T., Bonenberg A., Liu S., Garden - The Pursuit of Harmony in the Modern Times. NY USA, Proceedings of the AHFE, Springer 2021.

Bonenberg W., Bardzinska-Bonenberg T., Bonenberg A., Residences and Their Gardens. NY USA, Proceedings of the AHFE, Springer 2021.

Bręczewska-Kulesza D., Wysocka A., Od historyzmu do modernizmu. Bydgoskie wille miejskie i podmiejskie. Bydgoszcz, Stowarzyszenie Centrum Kultury Belle Époque 2017.

Brookes J., The Book of Garden Design. Hoboken NJ, USA, John Wiley \& Sons Inc 1991.

Conran T., Pearson D., Nowoczesne ogrody. Warszawa, Wydawnictwo Arkady 2000.

Czyżewski A., Trzewia Lewiatana. Miasta-ogrody i narodziny przedmieścia kulturalnego. Warszawa, Państwowe Muzeum Etnograficzne w Warszawie, 2009.

Frazer L.Ch., The Barbizon School (1830-1870): Expanding the Landscape of the Modern Art Market. Victoria, Canada, The Arbutus Review 8(1) 2017.

Hobhouse P., Historia ogrodów. Warszawa, Arkady Sp. z o.o. 2007.

Hunt, J. D., The Picturesque Garden in Europe. London, Thames \& Hudson 2003. 
Majdecki L., Historia ogrodów. Warszawa, PWN 1978.

Manning J. G., Land and Power in Ptolemaic Egypt: The Structure of Land Tenure. Cambridge, Cambridge University Press 2003.

Rozbicka M., Małe mieszkanie z ogrodem w tle w teorii i praktyce popularnego budownictwa mieszkaniowego w międzywojennej Polsce. Warszawa, Oficyna Wydawnicza Politechniki Warszawskiej 2007.

Thompson I., The Sun King's Garden: Louis XIV, Andre Le Notre and the Creation of the Gardens of Versailles. London, Bloomsbury Publishing PLC 2006.

Urbanik J., Wrocławska Wystawa Werkbundu WUWA 1929. Wrocław, Muzeum Architektury we Wrocławiu, Oficyna Wydawnicza Politechniki Wrocławskiej 2002.

Alvar Aalto Fondation, Maison Louis Carré. https://www.alvaraalto.fi/en/architecture/maison-louis-carre/\# access 2021-08-20

Bisgrove R., The Gardens of Gertrude Jekyll. University of California Press, Berkeley, 1992. https://books.google.pl/books?id=9sUSgLng4RIC\&pg=PA10\&dq=Gertrudę+Jekyll\&hl=pl\&sa=X\&ved=2ahU KEwih5PGh1NLzAhXoSvEDHfvZBHQQ6AF6BAgDEAI\#v=onepage\&q=Gertrudę\%20Jekyll\&f=false) access 2021-08-20

Brookes J., Garden Museum. Arts \& Culture, https://artsandculture.google.com/exhibit/johnbrookes/cAICdyEKB6xdIA access 2021-08-22

Le Corbusier, Kiedy katedry były białe. Paris 1937. https://pl.wikiquote.org/wiki/Le_Corbusier acc. 2021-08-28

Le Corbusier, Jeanneret $P$., Oeuvre complète, volume1, 1910-1929. access 2021-08-28 http://www.fondationlecorbusier.fr/corbuweb/morpheus.aspx?sysld=13\&lrisObjectld=6402\&sysLanguage= en-en\&itemPos=40\&itemCount $=215 \&$ sysParentld $=65 \&$ sysParentName $=$

Janick J., The Founding and Founders of the Royal Horticultural Society. Chronica Horticulturae. Vol 48, Number 1, 2008, pp.17--19. https://www.hort.purdue.edu/newcrop/pdfs/ch4801p17.pdf access 2021-08-28

Katechizm Kościoła Katolickiego. KKK 299, (Mdr 11, 20), https://www.teologia.pl/m_k/kkk1s13.htm access 2021-09-08

Lange \& Esters House. WikiArquitectura, access 2021-08-28

https://en.wikiarquitectura.com/building/lange-esters-house/,https://wp.eghn.org/en/haus-ester-haus-lange/

Lauterbach I., Landscape and Garden Design in 18th-Century Europe: Architectural Use of the Natural. Brewminate: We're Never Far from Where We Were, January 2018. https://brewminate.com/landscapeand-garden-design-in-18th-century-europe-architectural-use-of-the-natural/ access 2021-09-28

Mies van der Rohe Museum, Villa Wolf, Gubin. https://cargocollective.com/villawolfgubin/Villa-Wolf-Mies-vander-Rohe access 2021-08-28

Małecki J., Park zabytkowy w Kikole. Jeden z najpiękniejszych. https://arlan.pl/park-zabytkowy-w-kikole-jedenz-najpiekniejszych,59, pl.html access 2021-09-08

Modern Architecture Since 1900, Villa Stein. Design Library Image Collection 104818. access 2021-08-28

https://images.lib.ncsu.edu/luna/servlet/detail/NCSULIB 1 1 104818 176523:Villa-Stein-de-Monzie

Rice M., Who's Who in Ancient Egypt. London\&New York, Routledge 1999. access 2021-09-18

https://www.siamcostumes.com/cutters_guides/pdf/michael-rice-whos-who-in-ancient-egypt.pdf

Villa Tugendhat. Iconic Houses Org. https://www.iconichouses.org/specials/villa-tugendhat/history access 2021-08-28

Wirtz International. Great Gardens of the World, https://wirtznv.com/projects/ access 2021-08-28

\section{AUTHORS' NOTE}

Teresa Bardzinska-Bonenberg - D.Sc., Ph.D. in Architecture., Professor of Bydgoszcz University of Science and Technology, Bydgoszcz, Poland. In the years 2002-2015, Head of the Division of Architecture and Urban Planning at Poznan University of Technology. She is the author of adapting the curriculum of History of architecture to the requirements of the EU in order to introduce student exchanges. Nowadays, she lectures on the History of architecture and urban planning, Contemporary architecture, Conservation of architectural heritage and the Theory of architecture. She carried scientific grants of different types. Promotor of fifteen doctorates, including foreign students. For- 
eign teaching assignments conducted in Germany, Belarus, Ukraine, Italy and China. She worked at design offices in Poland and Scotland. Her recent research works deals with the history and present-day architecture, urbanization and gardens.

Agata Bonenberg - Full Professor and a Head of the Institute of Interior and Industry Design, at the Faculty of Architecture, Poznan University of Technology. Since 2014 has collaborated with Dipartimento di Architettura e Studi Urbani at Politecnico di Milano. She is a visiting professor at Chongqing Jiaotong University in China. In her professional career she worked for architectural practices throughout Germany, Australia, Scotland and Italy, including renowned Renzo Piano Building Workshop. In her research she deals with the subject of spaces that support, stimulate creativity and creative thinking. An expert in the field of universal and inclusive design. Author of utility models and patents.

\section{O AUTORACH}

Teresa Bardzińska-Bonenberg - Dr hab. inż. arch., Profesor Politechniki Bydgoskiej i Uniwersytetu Artystycznego w Poznaniu. W latach 2002- 2015 Kierownik Zakładu Historii Architektury i Urbanistyki na Politechnice Poznańskiej. Jest autorką przystosowania programu nauczania Historii Architektury do wymagań UE w celu wprowadzenia wymiany studentów. Obecnie wykłada Historię architektury i urbanistyki, Architekturę współczesną, Konserwację zabytków architektury i Teorię architektury. Zrealizowała granty naukowe różnych typów. Promotorka piętnastu doktoratów, w tym zagranicznych. Prowadziła zajęcia dydaktyczne za granicą w Niemczech, na Białorusi, Ukrainie we Włoszech i w Chinach. Pracowała w biurach projektowych w Polsce i Szkocji. W pracy badawczej zajmuje się historią i współczesnością architektury, urbanistyki i ogrodów.

Agata Bonenberg - Profesor zwyczajny i kierownik Instytutu Architektury Wnętrz i Wzornictwa Przemysłowego, na Wydziale Architektury Politechniki Poznańskiej. Od 2014 roku współpracuje z Dipartimento di Architettura e Studi Urbani na Politecnico di Milano. Jest profesorem wizytującym na Chongqing Jiaotong University w Chinach. W swojej karierze zawodowej pracowała dla biur architektonicznych w Niemczech, Australii, Szkocji i we Włoszech, w tym dla renomowanej pracowni Renzo Piano Building Workshop. W pracach badawczych zajmuje się tematyką przestrzeni wspierających, stymulujących kreatywność i twórcze myślenie. Ekspert w zakresie projektowania uniwersalnego i inkluzywnego. Autorka wzorów użytkowych i patentów.

Contact | Kontakt: teresa.bardzinska-bonenberg@pbs.edu.pl ; agata.bonenberg@put.poznan.pl 